OPEN ACCESS

Edited by:

Fumio Sakane,

Chiba University, Japan

Reviewed by:

Kaoru Goto,

Yamagata University School of

Medicine, Japan

Antonia Avila-Flores,

Centro Nacional de Biotecnologia -

CSIC, Spain

*Correspondence:

Xiao-Ping Zhong

Xiaoping.zhong@duke.edu

Specialty section:

This article was submitted to

Signaling,

a section of the journa

Frontiers in Cell and Developmental

Biology

Received: 31 August 2016

Accepted: 27 October 2016

Published: 10 November 2016

Citation:

Chen SS, Hu Z and Zhong X-P (2016)

Diacylglycerol Kinases in T Cell

Tolerance and Effector Function.

Front. Cell Dev. Biol. 4:130.

doi: 10.3389/fcell.2016.00130

\section{Diacylglycerol Kinases in T Cell Tolerance and Effector Function}

\author{
Shelley S. Chen ${ }^{1}$, Zhiming $\mathrm{Hu}^{1,2}$ and Xiao-Ping Zhong ${ }^{1,3,4 *}$ \\ ${ }^{1}$ Division of Allergy and Immunology, Department of Pediatrics, Duke University Medical Center, Durham, NC, USA, ${ }^{2}$ Institute \\ of Biotherapy, School of Biotechnology, Southern Medical University, Guangzhou, China, ${ }^{3}$ Department of Immunology, Duke \\ University Medical Center, Durham, NC, USA, ${ }^{4}$ Hematologic Malignancies and Cellular Therapies Program, Duke Cancer \\ Institute, Duke University Medical Center, Durham, NC, USA
}

Diacylglycerol kinases (DGKs) are a family of enzymes that regulate the relative levels of diacylglycerol (DAG) and phosphatidic acid (PA) in cells by phosphorylating DAG to produce PA. Both DAG and PA are important second messengers cascading $T$ cell receptor (TCR) signal by recruiting multiple effector molecules, such as RasGRP1, PKC $\theta$, and mTOR. Studies have revealed important physiological functions of DGKs in the regulation of receptor signaling and the development and activation of immune cells. In this review, we will focus on recent progresses in our understanding of two DGK isoforms, $\alpha$ and $\zeta$, in CD8 T effector and memory cell differentiation, regulatory T cell development and function, and invariant NKT cell development and effector lineage differentiation.

Keywords: diacylglycerol kinase, regulatory T cells, invariant NKT cells

\section{INTRODUCTION}

Diacylglycerol (DAG) and phosphatidic acid (PA) are two key lipid second messengers that facilitate efficient receptor-mediated signaling in immune cells along with many other cells. They regulate numerous intracellular signaling molecules to control cell differentiation, proliferation, survival, and function. Following T cell receptor (TCR) engagement, DAG is produced through the activation of Phospholipase $\mathrm{C} \gamma 1$ (PLC $\gamma 1$ ), which hydrolyzes membrane phosphatidylinositol bisphosphate $\left(\mathrm{PIP}_{2}\right)$ to DAG and inositol trisphosphate (IP3). DAG, together with other signal events, recruits downstream effector molecules to the membrane through their $\mathrm{C} 1$ domains and allosterically activates these effectors, with protein kinase $\mathrm{C} \theta(\mathrm{PKC} \theta)$, Ras guanyl-releasing protein 1 (RasGRP1), protein kinase D (PKD), Munc13s, and chimaerins being important for $\mathrm{T}$ cell development and/or function (Krishna and Zhong, 2013a; Merida et al., 2015).

DAG plays an important role in recruiting PKC $\theta$ to the plasma membrane and immune synapse in T cells (Diaz-Flores et al., 2003; Carrasco and Merida, 2004). The activation of PKC $\theta$ leads to TCR-mediated NF- $\mathrm{KB}$ and mammalian/mechanistic target of rapamycin complex 1 (mTORC1) activation in T cells (Sun et al., 2000; Isakov and Altman, 2002; Hamilton et al., 2014), which affects key processes, including T cell activation and survival (Manicassamy et al., 2006; Hayashi and Altman, 2007), IL-2 production (Werlen et al., 1998), $\mathrm{T}_{\mathrm{H}} 2$ responses (Cannons et al., 2004; Marsland et al., 2004), $\mathrm{T}_{\mathrm{H}} 17$ responses (Kwon et al., 2012), invariant NKT ( $i \mathrm{NKT}$ ) cell development and activation (Schmidt-Supprian et al., 2004; Fang et al., 2012), and Treg development (Gupta et al., 2008; Barnes et al., 2009; Medoff et al., 2009).

Ras guanyl-releasing protein 1 (RasGRP1) is another downstream molecule that is recruited to the cytoplasm membrane by DAG (Jones et al., 2002; Carrasco and Merida, 2004). RasGRP1 
promotes activation of Ras by exchanging GDP for GTP, leading to the activation of the RAF1-MEK1/2-ERK1/2 pathway (Ebinu et al., 1998; Dower et al., 2000; Roose et al., 2005). Additionally, RasGRP1-Ras-Erk1/2 pathway functions upstream for TCRinduced mTORC1, mTORC2, and PI3K activation in T cells (Gorentla et al., 2011). RasGRP1 plays an essential role in conventional $\alpha \beta$ T cell development (Dower et al., 2000; Fuller et al., 2012), particularly for the selection of thymocytes that express weak TCR signals (Priatel et al., 2002) and for early iNKT cell development (Shen et al., 2011a). While RasGRP1 appears dispensable for overall $\gamma \delta \mathrm{T}$ cell development, it ensures IL-17 expressing $\gamma \delta \mathrm{T} 17$ lineage differentiation and TCR-induced $\gamma \delta \mathrm{T}$ cell activation (Chen et al., 2012). More recently, it was also found that RasGRP1, together with RasGRP3, promotes early thymic precursor generation (Golec et al., 2016). Additionally, RasGRP1 may play a role in promoting antigen-induced CD8 cell expansion by lowering the threshold of $\mathrm{T}$ cell activation (Priatel et al., 2010).

PKDs are recruited by both DAG and DAG-activated PKCs. Upon stimulation, inactive PKDs translocate from the cytosol to the plasma membrane in response to membrane DAG production, where they are then activated by novel PKCs (Rozengurt et al., 2005; Spitaler et al., 2006). PKDs have been shown to exert different effects on VDJ recombination at the TCR $\beta$ locus and on CD4 and CD8 expression during T cell development based on their localization at the cytosol or plasma membrane (Marklund et al., 2003; Spitaler et al., 2006). Additionally, PKD2 acts as a sensitive digital amplifier of TCR engagement, enabling CD8 $\mathrm{T}$ cells to match the production of inflammatory cytokines to the quality and quantity of TCR ligands (Navarro et al., 2014).

Munc13 proteins are mammalian homologs of the C. elegans Unc13, which are important for neurotransmitter secretion (Brose and Rosenmund, 2002). Munc13-1, Munc13-2, and Munc13-3 isoforms bind to DAG with high affinity. The Munc13-4 isoform lacks a C1 domain (Koch et al., 2000; Shirakawa et al., 2004), but it is involved in granule maturation and exocytosis in NK cells and cytotoxic T lymphocytes (CTLs) (Feldmann et al., 2003; Menager et al., 2007), phagosomal maturation, and the killing of intracellular bacteria in neutrophils (Johnson et al., 2011; Monfregola et al., 2012). Deficiency of Munc13-4 causes primary immune deficiency in patients (Feldmann et al., 2003; Cichocki et al., 2014).

Chimaerins possess Rac-specific GTPase Activating Protein (GAP) activity (Caloca et al., 1999; Yang and Kazanietz, 2007). Chimaerin isoforms $\alpha 2$ and $\beta 2$ are expressed at different levels in $\mathrm{T}$ cells and have been shown to translocate to the immune synapse and to both participate in TCR signaling and receive regulation from it (Caloca et al., 2008; Siliceo and Merida, 2009). Chimaerins have been found to inhibit TCR-mediated NFAT activation and DAG-dependent actin polymerization to regulate $\mathrm{T}$ cell adhesion and chemotaxis (Siliceo et al., 2006).

Phosphatidic acid (PA) is produced both by the activity of DAG kinases (DGKs) and by the phospholipase D (PLD) family of enzymes in T cells. DGKs phosphorylate DAG to convert it to PA, while PLDs mediate the hydrolysis of phosphatidylcholine (Jenkins and Frohman, 2005; Zhong et al., 2008). The removal of PA is mediated by lipins, which can turn off PA-mediated signaling through dephosphorylation, and they have been shown to regulate mast cell function in the immune system (Csaki and Reue, 2010; Shin et al., 2013b). Intracellular levels of PA change dynamically in response to environmental stimuli (Wang et al., 2006). The downstream effector molecules of PA include a multitude of kinases, such as mTOR (Chen and Fang, 2002), phosphatidylinositol-4-phosphate 5-kinase (PIP5K) (Galandrini et al., 2005; Jarquin-Pardo et al., 2007; Micucci et al., 2008; Cockcroft, 2009; Yoon et al., 2011), spingosine kinase (SPHK 1/2), RAF1 (Ghosh et al., 1996; Shome et al., 1997; Rizzo et al., 1999, 2000; Andresen et al., 2002), and other molecules, such as Src homology region 2 domain-containing phosphatase 1 (SHP1) (Frank et al., 1999), kinase suppressor of Ras 1 (KSR1, a scaffolding protein that interacts with several components of the Raf-MEK-ERK cascade) (Morrison, 2001; Kraft et al., 2008), and Sos, another guanine nucleotide exchange factor for Ras activation (Zhao et al., 2007). Both PLD and DGK-derived PA has been shown to directly activate mTOR in non-T cells (Chen and Fang, 2002; Avila-Flores et al., 2005). In these cells, PA can also activate mTOR indirectly via ERK (Winter et al., 2010), but such a mechanism has not been examined in T cells. In T cells, DGK $\alpha$ and $\zeta$ mainly inhibit TCR-induced mTOR signaling by negative control of DAG-mediated RasGRP1 and likely PKC $\theta$ activation (Gorentla et al., 2011; Hamilton et al., 2014). However, DGK-derived PA has been shown to promote $\mathrm{T}$ cell maturation in the thymus (Guo et al., 2008) and to regulate innate immune responses (Liu et al., 2007). Future studies should determine the direct downstream of the effector(s) of PA that mediate its functions in these immune cells.

The diverse and important functions of DAG-and PA-mediated signaling suggest their levels must be tightly controlled temporally and spatially. DGKs switch from DAGmediated signals to PA-mediated signals to dynamically regulate downstream pathways in response to the engagement of the TCR and many other receptors (Merida et al., 2008; Cai et al., 2009; Zhong et al., 2011). In mammals, there are ten DGK isoforms encoded by different genes, some of which also contain splicing variants, adding complexity to this family of enzymes. All DGKs contain a kinase domain and at least two cysteine-rich $\mathrm{C} 1$ domains but differ in the homology of their other structural domains as well as their interaction with other biomolecules. Based on their structural distinction and homology, DGKs are classified into five types that may differ in subcellular localization, function, and regulation. The existence of multiple isoforms poses a significant challenge in studying the physiological roles of any specific isoforms in cellular development and functions due to functional redundancies, a fact demonstrated in conventional $\alpha \beta$ T cell and iNKT cell development in mice deficient in both DGK $\alpha$ and DGK $\zeta$ (Guo et al., 2008; Shen et al., 2011b). Of these ten isoforms, DGK $\alpha$ and DGK $\zeta$ as well as DGK $\delta$ are the major isoforms expressed in T cells (Zhong et al., 2002; Olenchock et al., 2006a; Sakane et al., 2007). Both DGK $\alpha$ and $\zeta$ have been found to regulate multiple signaling pathways downstream from the TCR (Zhong et al., 2002, 2003; Sanjuan et al., 2003; Baldanzi et al., 2011; Gharbi et al., 2011; Gorentla et al., 2011), such as the RasGRP1-Ras-Erk1/2 pathway, the PKC $\theta-I K K-N F \kappa B$ pathway, 
mTOR signaling (Gorentla et al., 2011), and MAP kinaseinteracting serine/threonine kinase (Mnk) 1 and 2 signaling (Gorentla et al., 2013). They control T cell development (Outram et al., 2002; Guo et al., 2008; Almena et al., 2013), activation and anergy (Zhong et al., 2003; Olenchock et al., 2006a; Zha et al., 2006; Baldanzi et al., 2011), survival (Baldanzi et al., 2011; Ruffo et al., 2016), secretion (Alonso et al., 2007, 2011; Chauveau et al., 2014), and effector function (Shin et al., 2012; Yang et al., 2016b). Besides T cells, DGK $\zeta$ also regulates the development, survival, and function of mast cells (Olenchock et al., 2006b), B cells (Wheeler et al., 2013), dendritic cells and macrophages (Liu et al., 2007), osteoclasts (Zamani et al., 2015), and NK cells (Yang et al., 2016a). Extensive reviews about DGKs in immune cells have been published recently (Merida et al., 2008, 2015; Zhong et al., 2008; Krishna and Zhong, 2013b). Here, we will focus on recent literature concerning DGKs in T cell tolerance, iNKT cell development and function, and CD8 T cell-mediated antimicrobial and antitumor immunity.

\section{DGK $\alpha$ AND DGKৎ IN T CELL TOLERANCE}

Clonal deletion of highly self-reactive $\mathrm{T}$ cells in the thymic medulla, generation of properly functioning regulatory $\mathrm{T}$ cells (Treg), and $\mathrm{T}$ cell anergy are among the most important mechanisms of $\mathrm{T}$ cell tolerance that prevent autoimmune diseases (Metzger and Anderson, 2011; Xing and Hogquist, 2012). Although DGK $\alpha$ and $\zeta$ synergistically promote $\mathrm{T}$ cell maturation from the $\mathrm{CD} 4{ }^{+} \mathrm{CD} 8^{+}$double positive (DP) to the $\mathrm{CD} 4^{+} \mathrm{CD} 8^{-}$ or $\mathrm{CD}^{-} \mathrm{CD}^{+}$single positive (SP) stage, no direct evidence has implicated DGK $\alpha$ and $\zeta$ in interference with negative selection in establishing central tolerance (Guo et al., 2008).

Regulatory $\mathrm{T}$ cells generated in the thymus (tTregs) dominantly suppress $\mathrm{T}$ cells and other immune cells to prevent autoimmune diseases. However, they also negatively regulate antitumor and antipathogen immune responses. tTregs are derived from CD4 SP thymocytes in the thymic medulla after relatively strong but transient TCR-MHC/peptide engagement and signaling (Mahmud et al., 2014; Li and Rudensky, 2016). They express Foxp3, a key transcription factor that is critical for their development, maintenance, and function. TCR signaling is not only essential for tTreg generation but also required for tTreg homeostasis and function (Kim et al., 2009; Delpoux et al., 2014; Levine et al., 2014; Vahl et al., 2014). Multiple DAGmediated signaling pathways are involved in tTreg development and function, indicated by the impaired tTreg development and function in mice deficient in either RasGRP1-Ras or PKC $\theta$ IKK-NFKB signaling. Both NFKB and AP1 are involved in transcriptional activation of Foxp3 expression and possibly in regulating other tTreg properties (Schmidt-Supprian et al., 2004; Willoughby et al., 2007; Chen et al., 2008; Gupta et al., 2008; Barnes et al., 2009; Medoff et al., 2009). Both the percentage and number of tTregs in the $\mathrm{CD}^{+}$population are increased in DGK $\zeta$-deficient (but not DGK $\alpha$-deficient) thymocytes and splenocytes, compared to wild-type (WT) controls (Table 1). Additionally, Foxp $3^{-} \mathrm{CD} 25^{+}$cells within the CD4 SP thymocytes are increased in a DGK $\zeta$-deficient thymus, suggesting that DGK $\zeta$ negatively controls early tTreg development. The inhibitory effect of DGK $\zeta$ on tTreg development is found to be dependent on its negative control of the NFKB/c-Rel and RasGRP1-Ras-Erk pathways (Joshi et al., 2013; Schmidt et al., 2013). Of note are reports that DGK $\alpha$ and $\zeta$ manifest differential effects on $\mathrm{TNF} \alpha-$ induced NFKB activation in tumor cells and fibroblasts, with DGK $\alpha$ positively regulating $\mathrm{PKC} \zeta$-mediated p65/RelA at serine 311 residue (Yanagisawa et al., 2007; Kai et al., 2009), while DGK $\zeta$ inhibits $\mathrm{TNF} \alpha$-induced $\mathrm{NF \kappa} \mathrm{B}$ activation via decreasing NFkB phosphorylation at Ser468/536, its nuclear localization, and its association with CBP (Tsuchiya et al., 2015). It would be interesting to investigate whether such mechanisms also operate in T cells or downstream of TCR to contribute to DGK $\alpha$ and $\zeta$ function in tTreg differentiation. It also remains unclear if DGK $\alpha$ and $\zeta$ act redundantly or synergistically to control Treg differentiation and function.

$\mathrm{T}$ cell anergy is a form of peripheral tolerance whereby $\mathrm{T}$ cells that recognize self-antigens in the absence of costimulatory signals are rendered functionally inactive (Schwartz, 2003; Powell, 2006; Fathman and Lineberry, 2007; Chappert and Schwartz, 2010; Kalekar et al., 2016). In anergic T cells, DAGmediated signaling, including Ras/Erk1/2, NFкB, and mTOR activation, is diminished, while $\mathrm{Ca}^{++}$-mediated signaling and NFAT are selectively elevated or unhindered (Powell, 2006; Chappert and Schwartz, 2010; Xie et al., 2012; Figure 1). Both DGK $\alpha$ and $\zeta$ are expressed at higher levels in anergic T cells than in activated T cells (Macian et al., 2002; Olenchock et al., 2006a; Zha et al., 2006). Deficiency of either DGK $\alpha$ or $\zeta$ or inhibition of DGK activity contributes $\mathrm{T}$ cell resistance to anergic induction (Olenchock et al., 2006a; Zha et al., 2006), while overexpression of DGK $\alpha$ promotes $\mathrm{T}$ cell anergy (Zha et al., 2006). Because DAG and IP3 are produced at an equimolar ratio by PLC $\gamma 1$ from PIP2, the elevated DGK $\alpha$ and $\zeta$ expression in anergic $\mathrm{T}$ cells may shift the equilibrium of IP3 and DAG toward the predominance of IP3-Ca ${ }^{++}$-NFAT signaling over DAG signaling and subsequent AP1 induction. NFAT forms a NFAT/AP1 dimer to promote $\mathrm{T}$ cell activation, but it also functions as a monomer to induce transcription of anergypromoting molecules, such as Cbl-b and TRAIL (Macian et al., 2002; Wu et al., 2006). It is postulated that elevated DGK activity may lead to NFAT monomer predominance over NFAT/AP1 dimer for anergy induction (Zhong et al., 2008; Krishna and Zhong, 2013a), although experimental evidence has not yet been presented.

An important issue is how DGK $\alpha$ and $\zeta$ expression is regulated. The transcription factor early growth response gene 2 (Egr2) is upregulated in anergic T cells and plays an important role in $\mathrm{T}$ cell anergy (Zheng et al., 2012). It binds directly to both $D g k a$ and $D g k z$ promoters to increase the expression of these genes as well as several other anergy-promoting genes (Zheng et al., 2012, 2013). Another transcription factor, Foxo1, also directly promotes Dgka transcription (MartinezMoreno et al., 2012). Foxo1 function, which is regulated by its subcellular localization between the cytosol and nuclei, is sequestered in the cytosolic compartment following Aktmediated phosphorylation, which prevents it from association with target genes. In naïve or unstimulated T cells, nuclear Foxo1 
TABLE 1 | Comparison of DGK $\alpha^{-/-}$, DGK $\zeta^{-/-}$, and DGK $\alpha^{-/-} \zeta^{-/-}$mice.

\begin{tabular}{|c|c|c|c|c|c|}
\hline & & $\mathrm{DGK}_{\zeta^{-1-}}$ & DGK $\alpha^{-/-}$ & $\mathrm{DGK}_{\alpha}-/-\zeta^{-/-}$ & References \\
\hline \multirow[t]{2}{*}{ T cell development } & Positive selection & Not affected & Not affected & $\begin{array}{l}\text { Severe decreases of CD4 SP } \\
\text { and CD8 SP thymocytes }\end{array}$ & $\begin{array}{l}\text { Zhong et al., 2003; } \\
\text { Olenchock et al., } \\
\text { 2006a; Guo et al., } 2008\end{array}$ \\
\hline & Negative selection & Not affected & Not affected & Not affected & Guo et al., 2008 \\
\hline \multirow[t]{3}{*}{ Regulatory $T$ cell } & $\begin{array}{l}\text { Foxp3 }{ }^{-} \mathrm{CD}^{2} 5^{+} \\
\mathrm{CD}^{+} \mathrm{SP} \text { thymocytes }\end{array}$ & Increased frequencies & $\begin{array}{l}\text { Increased but less obvious than } \\
\mathrm{DGK}^{-/-}\end{array}$ & Not reported & $\begin{array}{l}\text { Joshi et al., 2013; } \\
\text { Schmidt et al., } 2013\end{array}$ \\
\hline & Foxp3 ${ }^{+}$Treg & $\begin{array}{l}\text { Increased in thymus and } \\
\text { spleen }\end{array}$ & Not increased & Not reported & Schmidt et al., 2013 \\
\hline & $\begin{array}{l}\text { Suppressive function } \\
\text { (in vitro) }\end{array}$ & Enhanced & Not obviously changed & Not reported & Schmidt et al., 2015 \\
\hline \multirow[t]{2}{*}{ iNKT cells } & iNKT cell numbers & Not affected & Not affected & Severely decreased & Shen et al., 2011b \\
\hline & iNKT17 cell & $\begin{array}{l}\text { Decreased in numbers due } \\
\text { to extrinsic mechanisms }\end{array}$ & Not reported & Not reported & Wu et al., 2013 \\
\hline \multirow[t]{5}{*}{ CD8 T cells } & $\begin{array}{l}\text { Primary responses to } \\
\text { pathogens }\end{array}$ & $\begin{array}{l}\text { Enhanced expansion and } \\
\text { cytokine production in } \\
\text { response to LCMV }\end{array}$ & $\begin{array}{l}\text { Less obvious expansion than } \\
\text { DGK } \zeta^{-/-} \text {but similar enhanced } \\
\text { cytokine production in response } \\
\text { to LCMV }\end{array}$ & $\begin{array}{l}\text { Severely impaired in migration, } \\
\text { expansion, and cytokine } \\
\text { production in response to } \\
\text { LM-Ova }\end{array}$ & $\begin{array}{l}\text { Zhong et al., 2003; } \\
\text { Shin et al., 2012; Yang } \\
\text { et al., 2016b }\end{array}$ \\
\hline & Memory responses & $\begin{array}{l}\text { Decreased formation; } \\
\text { impaired in expansion, } \\
\text { enhanced IFN } \gamma \text { and TNF } \alpha \\
\text { production in recall } \\
\text { responses to LCMV }\end{array}$ & $\begin{array}{l}\text { Decreased formation; impaired in } \\
\text { expansion (more severe than } \\
\text { DGK } \zeta^{-/-} \text {), enhanced IFN } \gamma \text { but } \\
\text { not TNF } \alpha \text { production in recall } \\
\text { responses to LCMV }\end{array}$ & $\begin{array}{l}\text { Impaired formation and } \\
\text { maintenance; Decreased } \\
\text { expansion but enhanced IFN } \gamma \\
\text { and TNF } \alpha \text { production in recall } \\
\text { response to LM-Ova }\end{array}$ & $\begin{array}{l}\text { Shin et al., 2012; Yang } \\
\text { et al., 2016b }\end{array}$ \\
\hline & Sensitivity to TGF- $\beta$ & Decreased & Not reported & Not reported & Arumugam et al., 2015 \\
\hline & $\begin{array}{l}\text { Anti-tumor } \\
\text { immunity-OT1 T cells }\end{array}$ & $\begin{array}{l}\text { Enhanced expansion and } \\
\text { effector function; Enhanced } \\
\text { tumor control }\end{array}$ & Not reported & Not reported & Riese et al., 2011, 2013 \\
\hline & $\begin{array}{l}\text { Anti-tumor } \\
\text { immunity-Meso-CAR T } \\
\text { cells }\end{array}$ & Enhanced effector function & Enhanced effector function & $\begin{array}{l}\text { Stronger effector function than } \\
\text { DGK } \alpha \text { or } \zeta \text { single deficiency; } \\
\text { Better tumor control }\end{array}$ & Riese et al., 2013 \\
\hline
\end{tabular}

activates $D g k a$ expression. TCR engagement in the presence of CD28 costimulation induces strong PI3K/Akt activation, which may reduce nuclear Foxo1 and subsequent DGK $\alpha$ expression to ensure full $\mathrm{T}$ cell activation and avoidance of anergy (MartinezMoreno et al., 2012). DGKל expression has also been found to be regulated by microRNA. Two conserved sequences that match to the miR-34a seed sequence are located in the coding region and $3^{\prime}$ untranslated region ( $3^{\prime}$ UTR) of Dgkz. miR-34a expression is greatly upregulated in activated $\mathrm{T}$ cells. miR-34a directly represses DGK $\zeta$ expression through targeting both $\mathrm{Dgkz}$ $3^{\prime}$ UTR and the coding region to promote T cell activation (Shin et al., 2013a).

\section{DGKS IN INKT CELL DEVELOPMENT AND FUNCTION}

Invariant NKT (iNKT) cells express the invariant V $\alpha 14$ J $\alpha 18$ TCR, which recognizes lipid antigens presented by MHC class I-like CD1d molecules (Kawano et al., 1997; Mendiratta et al., 1997; Gapin et al., 2001). They are derived from a unique innatelike lymphoid cell lineage and can rapidly respond to agonist stimulation in both innate and adaptive immune responses via production of cytokines, such as IL-4, IL-17, IL-10, IL-13, IFN $\gamma$, and TNF $\alpha$ (Bendelac et al., 2007; Coquet et al., 2008; Godfrey et al., 2010; Milpied et al., 2011; Brennan et al., 2013; Salio et al., 2014). iNKT cells participate in host defense against microbial infection, antitumor immunity, and many diseases, such as allergies, asthma, graft-vs.-host disease, and obesity (Osman et al., 2000; Terashima et al., 2008; Van Kaer et al., 2013; Berzins and Ritchie, 2014).

Based on surface CD24, CD44, and NK1.1 expression, iNKT cells are traditionally defined by four developmental stages in the thymus: stage $0\left(\mathrm{CD} 24^{+} \mathrm{CD} 44^{-} \mathrm{NK} 1.1^{-}\right)$, stage 1 $\left(\mathrm{CD} 24^{-} \mathrm{CD} 44^{-} \mathrm{NK} 1.1^{-}\right)$, stage $2\left(\mathrm{CD} 24^{-} \mathrm{CD} 44^{+} \mathrm{NK} 1.1^{-}\right)$, and stage $3\left(\mathrm{CD}^{2} 4^{-} \mathrm{CD} 44^{+} \mathrm{NK} 1.1^{+}\right)$(Bendelac et al., 2007; Godfrey et al., 2010; Figure 2). Recently, iNKT cells have also been defined into multiple terminally differentiated effector lineages, such as IFN- $\gamma$-producing iNKT1, IL-4-producing iNKT2, and IL-17producing iNKT17 lineage (Matsuda et al., 2006; Michel et al., 2007, 2008). In addition, IL-10-producing iNKT10, T follicular helper (Tfh)-like iNKT cells (iNKT $\mathrm{FH}_{\mathrm{FH}}$ ), and regulatory $\mathrm{T}$ cell (Treg)-like iNKT cells have also recently been described (Chang et al., 2012; Tonti et al., 2012; Sag et al., 2014; Lynch et al., 2015; Rampuria and Lang, 2015). iNKT1 and iNKT17 cells mostly reside in the $\mathrm{CD} 44^{+} \mathrm{NK} 1.1^{+}$and the $\mathrm{CD}_{4}{ }^{+} \mathrm{NK} 1.1^{-} \mathrm{ICOS}^{+}$ 


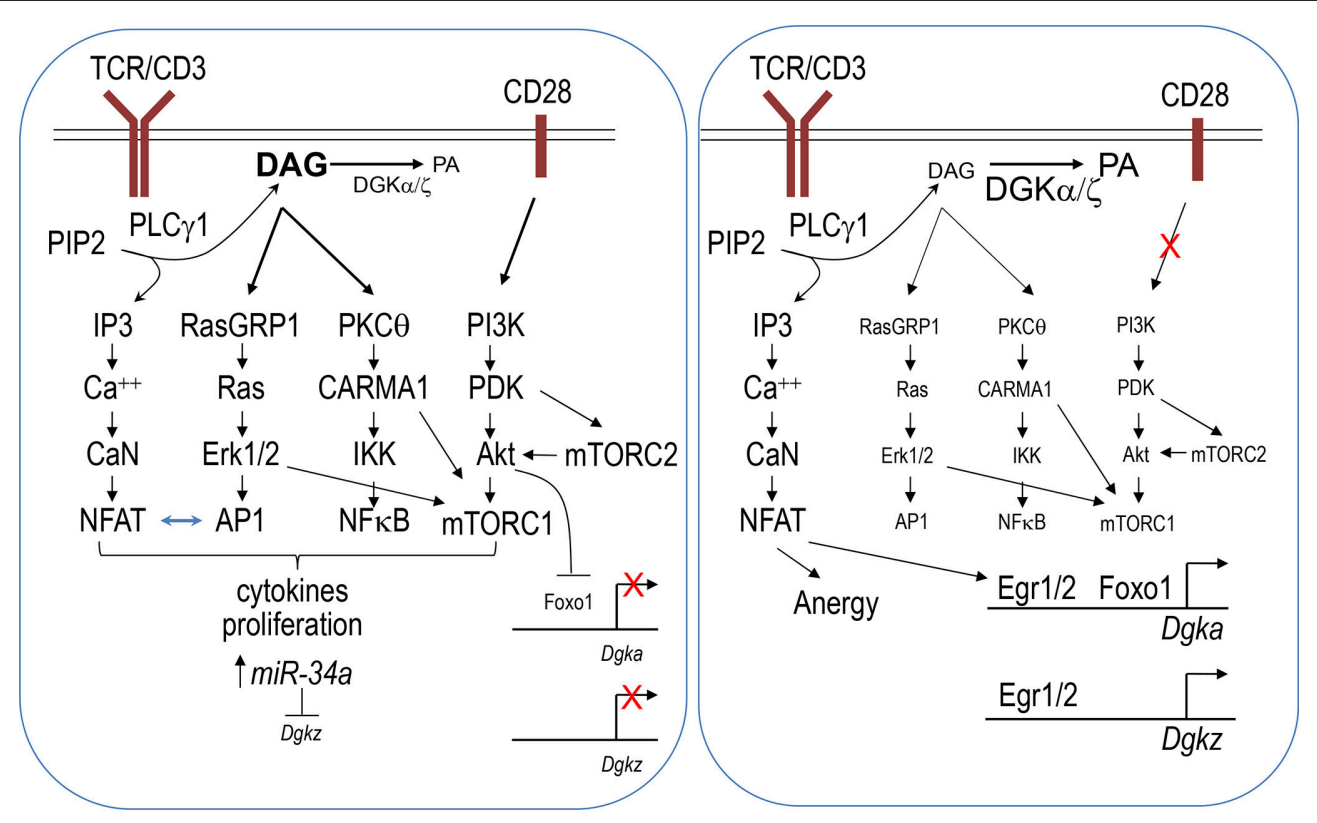

FIGURE 1 | DGK $\alpha$ and DGK $\zeta$ in T cell activation and anergy. Engagement of the TCR in the presence of co-stimulation results in strong activation of the PI3K-PDK1-Akt pathway (left panel). This pathway leads to mTORC2 signaling. Together with activation of the RasGRP1/Ras-Erk1/2 and PKC - -CARMA1 pathways, they leads to mTORC1 activation. mTORC2 also promotes Akt activation via phosphorylation. Activated Akt phosphorylates Foxo1, leading to it sequestration in the cytosol and failure to activate DGKa transcription. In activated T cells, miR-34a is upregulated, which in turn downregulates DGK $\zeta$ expression. Decreased DGK $\alpha$ and $\zeta$ expression leads to strong DAG-mediated signaling including increases of AP-1 and NFKB activity. AP-1 associates with NFAT to promote T cell activation. At the same time, AP-1 reduces monomeric NFAT to prevent it from inducing anergy promoting molecules. Strong DAG signaling together with IP3-CaN (calcineurin)-NFAT signaling allows full activation of T cells. In contrast, engagement of TCR in the absence of co-stimulation decreases PI3K-Akt-mTOR signaling, leading to increased

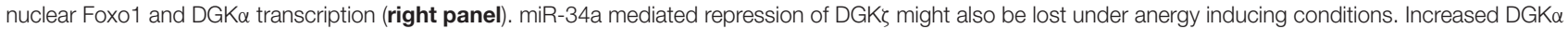
and $\zeta$ expression may lead to a skewed balance between IP3 and DAG toward strong or selective $\mathrm{Ca}^{++}$-NFAT signaling and induction of Egr1/2, which further induce transcription of DGK $\alpha$ and DGKל as well as other anergy promoting molecules. Selective IP3-Ca ${ }^{++}$-NFAT signaling in the presence of weak DAG-mediated signaling induces $T$ cells to enter an anergic state.

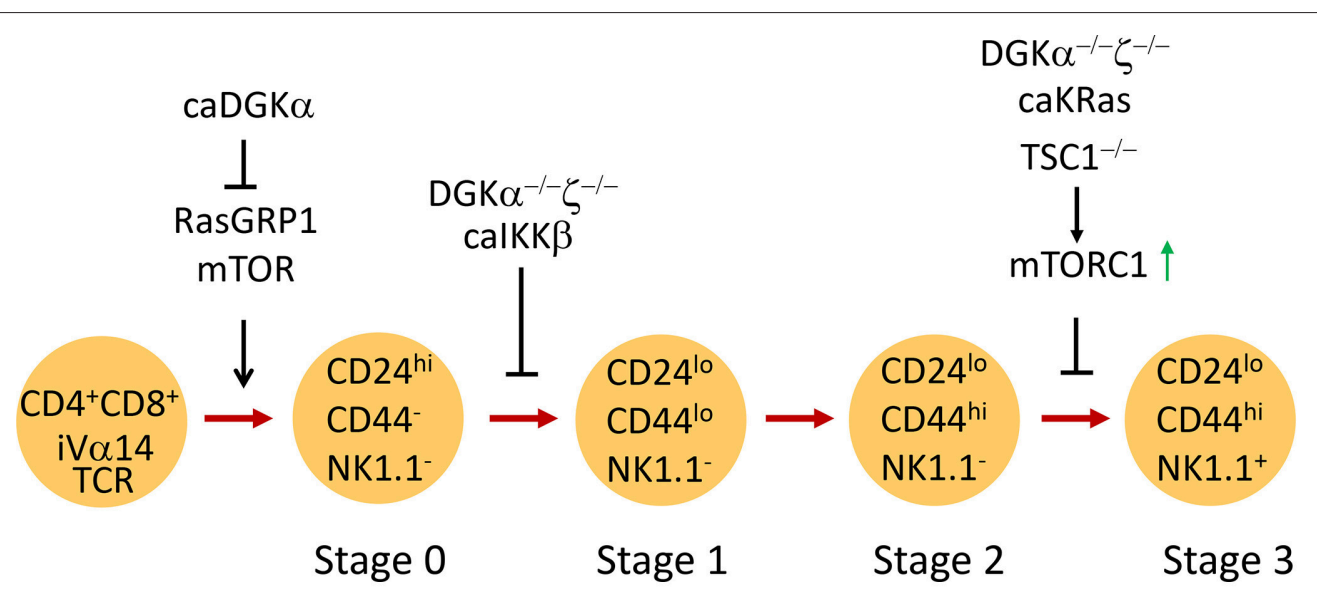

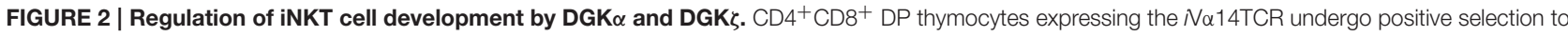
become iNKT cells. RasGRP1/mTOR signaling is critical for generation of stage 0 iNKT cells. Constitutive DGKa inhibits iNKT generation possibly by inhibiting RasGRP1/Erk1/2 activation. DGK $\alpha$ and $\zeta$ double deficiency or overactivation of IKK $\beta$ causes similar blockade of early iNKT cell development. Overactivation of mTORC1 due to TSC1 deficiency leads to blockade of iNKT terminal maturation. DGKa and $\zeta$ double deficiency or expression of a constitutively active KRas also results in impaired iNKT terminal maturation, correlated with elevated mTORC1 activation. 
populations, respectively (Watarai et al., 2012; Constantinides and Bendelac, 2013; Lee et al., 2013; Wu et al., 2014b).

Both the RasGRP1-Ras-Erk1/2 and PKC $\theta$-IKK-NFкB pathways have been shown to play important roles in iNTK cell development (Yang et al., 2015). Although it was initially thought that Ras and Erk1/2 activation were dispensable for iNKT cell ontogeny, two recent studies have provided evidence that the RasGRP1-Ras-Mek1/2-Erk1/2 pathway is critical for early iNKT cell development (Hu et al., 2011; Shen et al., 2011a). In RasGRP1-deficient mice, stage 0 iNKT cells as well as total iNKT cell count are significantly decreased, suggesting defective positive selection (Shen et al., 2011a). In concordance with these observations, mice expressing dominant negative Ras in developing thymocytes demonstrated iNKT cell developmental defects (Hu et al., 2011). The RasGRP1-Ras-Erk1/2 pathway activates mTORC1 and mTORC2 signaling as well as Mnk1/2 in developing thymocytes (Gorentla et al., 2011, 2013). Both mTORC1 and mTORC2, but not Mnk1/2, are important for early iNKT cell development (Gorentla et al., 2013; Shin et al., 2014; Wei et al., 2014; Zhang et al., 2014; Prevot et al., 2015), revealing a RasGRP1-Ras-Erk1/2-mTOR signal cascade in iNKT cells for their development. mTORC1, but not mTORC2, promotes PLZF nuclear localization, which may ensure iNKT cell maturation in stage 1 and differentiation to cytokine-producing cells (Shin et al., 2014; Prevot et al., 2015). In iNKT cells, both the DAG and the SLAM (signaling lymphocytic-activation molecule)-SAP (SLAM adaptor protein)-FynT pathway are involved in PKC $\theta$ and subsequent $\mathrm{NF \kappa B}$ activation. The PKC $\theta$-IKK-NFkB pathway is essential in the ontogeny of iNKT cells, at least in part by increasing expression of antiapoptotic proteins, such as $\mathrm{Bcl}-\mathrm{xL}$ (Elewaut et al., 2003; Sivakumar et al., 2003; Schmidt-Supprian et al., 2004; Stanic et al., 2004; Chung et al., 2005; Nichols et al., 2005; Pasquier et al., 2005; Griewank et al., 2007; Fang et al., 2012), but it is independent of CARMA1 and Malt1 (Mucosaassociated lymphoid tissue lymphoma translocation protein 1) (Medoff et al., 2009). CARMA1 contributes to TCR-induced mTORC1 activation in T cells (Hamilton et al., 2014). Given the minimal requirement of CARMA1 for iNKT cell development, it would be interesting to determine if TCR-induced mTORC1 activation in iNKT cells would be independent of CARMA1.

Emerging evidence demonstrates that tight regulation of DAG-mediated signaling by DGK activity is critical for the development of iNKT cells. Elevated DGKa activity brought about by expressing a membrane-targeted caDGK $\alpha$ in thymocytes under the control of the proximal Lck promoter caused reduced Erk1/2 activation in thymocytes and a 50\% decrease of thymic iNKT cells (Almena et al., 2013). Germline deletion of either DGK $\alpha$ or $\zeta$ did not significantly alter iNKT cell numbers in mice. However, simultaneous ablation of both enzymes resulted in a drastic decrease in the number of iNKT cells in the thymus and in peripheral lymphoid organs (Shen et al., 2011b), correlated with prolonged DAG accumulation, elevated Ras-Erk1/2 and PKC $\theta$-IKK signaling, and enhanced activation of both mTORC1 and mTORC2 activities in DP thymocytes (Guo et al., 2008; Gorentla et al., 2011). In DGKa and $\zeta$ double knockout mice, there was a decrease in the number of stage 1 to stage 3 iNKT cells. Stage 0 iNKT cells were not examined. The remaining iNKT cells in these mice were mostly CD $44^{+} \mathrm{NK} 1.1^{-}$stage 2 cells, suggesting that DGK $\alpha$ and $\zeta$ promote both early and terminal iNKT cell maturation (Shen et al., 2011b). Interestingly, expression of constitutive active (CA) IKK $\beta$ in developing thymocytes caused a severe reduction in the number of stage 1-3 iNKT cells. Thus, DGK $\alpha$ and $\zeta$ double deficiency may cause dysregulation of the PKC $\theta-\mathrm{IKK}-\mathrm{NFKB}$ pathway, leading to early iNKT cell developmental blockage. Different from CA-IKK $\beta$, expression of CA-KRas in thymocytes caused a selective blockage of the transition from stage 2 to 3 of iNKT cells and was associated with decreased T-bet expression (Shen et al., 2011b). Because CA-KRas and DGK $\alpha$ and $\zeta$ double deficiency caused elevated mTORC1 signaling (Gorentla et al., 2011) and overactivation of mTORC1 in the absence of TSC 1 also resulted in a similar iNKT cell terminal maturation defect (Wu et al., 2014b), DGK $\alpha$ and $\zeta$ may synergistically promote iNKT cell terminal maturation at least in part by preventing overactivation of the RasGRP1-Ras-Erk1/2-mTORC1 signaling cascade.

The role of DGKs in iNKT effector functions, however, is less clear. DAG-mediated signaling pathways play important roles in $\mathrm{T}$ cell activation, effector lineage differentiation, and tolerance (Chen et al., 2012). They are thus expected to be important in iNKT activation and function. For example, PKC $\theta$ is essential for iNKT-mediated liver inflammation (Fang et al., 2012). In germline DGK -deficient mice, iNKT17, but not iNKT1 cell number, was selectively decreased. Interestingly, iNKT-17 defects caused by DGKל deficiency can be corrected

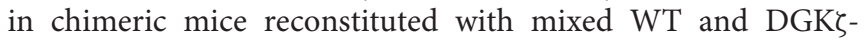
deficient bone marrow cells, suggesting that DGKל controls iNKT-17 differentiation via an extrinsic mechanism (Wu et al., 2013). Future investigation should define the type of cells that

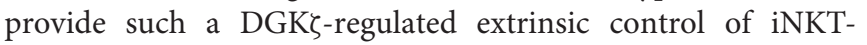
17 development. Additionally, mTORC1 deficient iNKT cells are defective in activation and are not able to inflict liver damage (Shin et al., 2014). Overactivation of mTORC1 due to TSC1 deficiency shapes iNKT cell effector lineage fates and contributes to their resistance to anergy and enhanced antitumor immunity (Wu et al., 2014a,b). Given the ability of DGKs in regulating $\mathrm{mTOR}$ and $\mathrm{PKC} \theta$ signaling, future studies should determine if DGKs intrinsically regulate iNKT cell functions and effector lineage differentiation under steady state and in various pathologic conditions.

\section{DGK $\alpha$ AND $\zeta$ IN CD8 T CELL-MEDIATED ANTIPATHOGEN IMMUNE RESPONSES}

CD8 $\mathrm{T}$ cells play important roles in immune responses against pathogens, particularly intracellular pathogens. Upon microbial infection, naïve CD8 $\mathrm{T}$ cells are activated after engagement of their TCRs with pathogen-derived peptides presented by antigenpresenting cells. They massively expand and differentiate into cytotoxic $\mathrm{T}$ cells that are equipped to kill pathogen-infected target cells and secrete proinflammatory cytokines. A typical antigenspecific CD8 T cell-mediated response includes an expansion phase in which CD8 cells proliferate rapidly and differentiate into effector cells, a contraction phase in which $90-95 \%$ of effector 
CD8 cells die due to apoptosis, and a memory maintenance phase in which the remaining $5-10 \%$ of cells are retained as fast-responding memory cells (Williams et al., 2006; Harty and Badovinac, 2008; Zhang and Bevan, 2011). During the expansion phase, effector CD8 T cells differentiate into short-lived effector cells (SLECs, CD127 ${ }^{\text {low }}$ KLRG1 ${ }^{\text {hi }}$ ) and memory precursor effector cells (MPECs, CD127 ${ }^{\text {hi }}$ KLRG1 ${ }^{\text {low }}$ ) (Kaech et al., 2003; Sarkar et al., 2008). SLECs produce high levels of cytokines but are prone to death, while MPECs have high potential to differentiate to long-lived memory cells.

Engagement of the TCR on naïve CD8 T cells provides a critical signal that initiates their activation and expansion. TCR signal strength and quality regulate both the magnitude of expansion and the effector fates of CD8 T cells (Zehn et al., 2009; Iborra et al., 2013; Marchingo et al., 2014; Fulton et al., 2015) through the Ras-Erk1/2-AP1 and PKC $\theta-\mathrm{IKK}-\mathrm{NF} \kappa \mathrm{B}$ signaling pathways (Sun et al., 2000; Priatel et al., 2002; Zhong et al., 2008; Merida et al., 2015). An initial study found that DGK $\zeta$ deficient mice mounted an enhanced antiviral immune response following lymphocytic choriomeningitis virus (LCMV) infection. These mice showed enhanced expansion of viral-specific effector CD4 and CD8 T cells that contained higher percentages of IFN $\gamma$ producing cells 7 days after LCMV infection, which resulted in a quicker clearance of the virus than in WT mice (Zhong et al., 2003). A subsequent study further revealed that DGK $\alpha$ and $\zeta$ differentially regulate effector and memory CD8 T cell differentiation. While a deficiency of either DGK $\alpha$ or $\zeta$ resulted in enhanced effector CD8 T cell expansion, it slightly decreased memory CD8 T cell formation and response to LCMV infection, which correlated with elevated mTORC1 signaling in these cells (Shin et al., 2012).

Although deficiency of either DGK $\alpha$ or $\zeta$ enhances antiviral immune responses, DGK $\alpha$ and $\zeta$ double deficiency actually caused severe impairment of CD8 T cell-mediated responses to Listeria monocytogenes (LM) infection (Yang et al., 2016b). In an ovalbumin (OVA) specific OT1 TCR transgenic model and newly generated floxed DGK $\zeta$ conditional-deficient mice where DGK $\alpha$ and $\zeta$ activity can be selectively deleted in naïve and memory CD8 T cells, it was found that ablation of both DGK $\alpha$ and $\zeta$, but not of the individual DGK $\alpha$ or $\zeta$ isoform, impaired primary CD8 T cell responses (Table 1). At the earliest hours after LM-OVA infection, DGK $\alpha$ and $\zeta$ double deficient CD8 T cells expressed decreased levels of chemokine receptors CCR4, CCR5, and CXCR3 and showed impaired migration to the draining lymph nodes (dLNs). Cells that migrated to the dLNs were compromised in their proliferative ability due to not yet defined mechanism(s). In contrast to this in vivo setting, DGK $\alpha$ and $\zeta$ double deficient CD8 $\mathrm{T}$ cells proliferated more vigorously than WT controls in vitro following antigen stimulation, suggesting that the defect in proliferation was not due to intrinsic defects. It would be interesting to determine if DGK $\alpha$ and $\zeta$ are involved in regulating $\mathrm{T}$ cell/APC engagement for initiation of $\mathrm{T}$ cell activation. As a consequence of impaired expansion of DGK $\alpha$ and $\zeta$ double deficient CD8 $\mathrm{T}$ cells during primary immune responses, formation of memory cells was severely decreased as well. In addition, DGK $\alpha$ and $\zeta$ double deficiency compromised memory CD8 T cell function in homeostasis. Ablation of DGK $\alpha$ and $\zeta$ in preformed memory CD8 T cells accelerated the decline of these cells due to increased death and decreased homeostatic proliferative renewal (Yang et al., 2016b).

In DGK $\alpha$ and $\zeta$ double deficient CD8 T cells, TCR-induced NFKB nuclear localization was surprisingly diminished, although nuclear NFKB was elevated before stimulation (Yang et al., 2016b). A similar situation was also observed in T cells expressing a constitutive active IKK $\beta$. CD8 T cells expressing a constitutive active IKK $\beta$ are defective in expansion in vivo following LMOVA infection and are impaired in TCR-induced nuclear NFKB translocation (Krishna et al., 2012). It is likely, then, that elevated DAG levels may lead to an increase of basal activation of the PKC $\theta$-IKK-NFKB pathway, which may trigger a negative feedback inhibition for TCR-induced activation of this pathway. Further studies should illustrate the exact negative feedback mechanism caused by DGK $\alpha$ and $\zeta$ double deficiency and by overactivation of IKK $\beta$.

One consequence of decreased NFKB activation in DGK $\alpha$ and $\zeta$ double deficient CD8 T cells was decreased miR-155 expression and, subsequently, increased SOCS1 expression (Yang et al., 2016b). miR-155 promotes expansion of effector CD8 T cells and generation of memory CD8 T cells by targeting SOCS1 expression to ensure signaling from the common $\gamma(\gamma \mathrm{c})$ chain cytokine receptors (Dudda et al., 2013; Gracias et al., 2013). Common $\gamma$ chain receptor signaling is known to be critical for CD8 effector and memory responses (Becker et al., 2002; Kieper et al., 2002; Carrio et al., 2004; Bachmann et al., 2007; Cui and Kaech, 2010; Sandau et al., 2010; Feau et al., 2011; Boyman and Sprent, 2012; Van Der Windt et al., 2012; StarbeckMiller et al., 2014; Cui et al., 2015); SOCS1 negatively controls signaling from these $\gamma c$-chain cytokine receptors (Cornish et al., 2003). Overexpression of miR-155 restored signaling from these receptors in DGK $\alpha$ and $\zeta$ double deficient CD8 T cells and partially corrected their defective responses. The data identified a DGK-NFKB-miR-155-SOCS1 axis that bridges TCR and $\gamma$ c-chain cytokine signaling for robust CD8 T-cell primary and memory responses to bacterial infection (Yang et al., 2016b).

\section{DGK $\alpha$ AND $\zeta$ REGULATE CD8 T CELL AND CAR-T CELL MEDIATED ANTITUMOR IMMUNITY}

A tumor microenvironment suppresses $\mathrm{T}$ cell mediated antitumor immunity, rendering tumor-infiltrating $\mathrm{T}$ cells hyporesponsive or anergic (Abe and Macian, 2013; Crespo et al., 2013). DGK $\zeta$-deficient CD8 T cells contain elevated antitumor immunity. DGK $\zeta$-deficient mice subcutaneously injected with the EL-4 thymoma had reduced tumor burdens and increased tumor-specific proliferative CD8 effector T cells compared to WT controls (Riese et al., 2011, 2013). Both increased Erk1/2 activation and decreased sensitivity to the suppressive cytokine TGF- $\beta$ in DGK $\zeta$-deficient CD8 T cells may be responsible for stronger activation and antitumor immunity (Arumugam et al., 2015).

Recently, chimeric antigen receptor (CAR) T cells (CAR-T cells) have demonstrated superior activity in tumor control and, 
in some cases, tumor eradication (Fesnak et al., 2016). However, CAR-T cells have manifested limited efficacy for solid tumors in that they are subjected to suppression by the local tumor environment and may become hyporesponsive or anergic. Such hyporesponsive or anergic tumor-infiltrating $\mathrm{T}$ cells or CAR$\mathrm{T}$ cells show decreased Ras/Erk activation but elevated DGK $\alpha$ and $\zeta$ levels (Moon et al., 2014). Both type 1 and type 2 DGK inhibitors are capable of reversing such hyporesponsiveness in tumor-infiltrating CAR-T cells ex vivo, leading to increased cytotoxicity (Moon et al., 2014). Consistent with this finding, genetic ablation of DGK $\alpha, \zeta$, or both DGK $\alpha$ and $\zeta$ enhanced CD8 $\mathrm{T}$ cells transduced with a mesoCAR, a CAR with high affinity to the human tumor antigen mesothelin. DGK $\alpha$ and $\zeta$ single or double deficient mesoCAR-T cells produced elevated IFN $\gamma$ production and demonstrated stronger antitumor cytotoxicity than WT controls, which correlated with reduced sensitivity to TGF $\beta$ and increased expression of FasL and TRAIL, ligands for the death receptors FAS and TRAIL-RI/RII. Importantly, DGKdeficient mesoCAR-T cells controlled mesothelioma in vivo better than WT controls (Riese et al., 2013). The enhancement of CAR-T function by DGK $\alpha$ and $\zeta$ double deficiency sharply contrasts with the defective anti-LM responses of DGK $\alpha$ and $\zeta$ double deficient CD8 T cells, suggesting differential requirements of DAG-mediated signaling downstream of CARs and TCR and for CAR-T and conventional CD8 T cell activation.

\section{SUMMARY}

Over the past few years, our understanding of the DGK family of enzymes in immune cells has been significantly advanced. DGK $\alpha$ and $\zeta$ act individually to negatively control $\mathrm{T}$ cell activation, effector CD8 $\mathrm{T}$ cell differentiation and function during antimicrobial and antitumor immune responses, and tTreg generation. DGK $\alpha$ and $\zeta$ also manifest functional redundancy in promoting conventional $\alpha \beta \mathrm{T}$ cell and iNKT cell development and in enhancing CAR-T cell function. The unexpected severe impairment of CD8 T cell-mediated immune responses to microbial infection in the absence of

\section{REFERENCES}

Abe, B. T., and Macian, F. (2013). Uncovering the mechanisms that regulate tumor-induced T-cell anergy. Oncoimmunol 2:e22679. doi: 10.4161/onci.22679

Almena, M., Andrada, E., Liebana, R., and Merida, I. (2013). Diacylglycerol metabolism attenuates $\mathrm{T}$-cell receptor signaling and alters thymocyte differentiation. Cell Death Dis. 4:e912. doi: 10.1038/cddis.2013.396

Alonso, R., Mazzeo, C., Mérida, I., and Izquierdo, M. (2007). A new role of diacylglycerol kinase $\alpha$ on the secretion of lethal exosomes bearing Fas ligand during activation-induced cell death of T lymphocytes. Biochimie 89, 213-221. doi: 10.1016/j.biochi.2006.07.018

Alonso, R., Mazzeo, C., Rodriguez, M. C., Marsh, M., Fraile-Ramos, A., Calvo, V., et al. (2011). Diacylglycerol kinase $\alpha$ regulates the formation and polarisation of mature multivesicular bodies involved in the secretion of Fas ligandcontaining exosomes in T lymphocytes. Cell Death Differ. 18, 1161-1173. doi: 10.1038/cdd.2010.184

Andresen, B. T., Rizzo, M. A., Shome, K., and Romero, G. (2002). The role of phosphatidic acid in the regulation of the Ras/MEK/Erk both DGK $\alpha$ and $\zeta$ underscores the importance of fine-tuning DAG levels and also suggests potential negative feedback mechanisms triggered by deregulated DAG-mediated signaling. Defining such mechanisms should shed additional light on the regulation of DAG-mediated signaling pathways. Additional efforts are also needed to illustrate the underlying mechanisms of differential effects of DGK $\alpha$ and $\zeta$ double deficiency on CD8 $\mathrm{T}$ cells during antitumor and antipathogen immune responses. While $\mathrm{DGK} \alpha$ and $\zeta$ perform similar or redundant functions, a more prominent role of DGK $\zeta$ than $D G K \alpha$ in certain aspects of $\mathrm{T}$ cell biology, such as effector CD8 $\mathrm{T}$ cell differentiation and Treg, development has been noted (Table 1); however, determinants of such differences between DGK $\alpha$ and $\zeta$ remain unclear. The drastic differences observed between DGK $\alpha$ and $\zeta$ double and single deficient CD8 T cells during immune responses beg for development of DGK isoform-specific inhibitors. Such inhibitors used individually or in combination may provide great advantages over panDGK inhibitors in modulating immune responses for therapeutic purposes in different disease settings to minimize undesirable side effects. Key elements, such as transcription factors, microRNAs, and posttranslational modifications that control the dynamic individual and synergistic functions of DGK isoforms in $\mathrm{T}$ cells are beginning to be appreciated and require further exploration for better understanding of their physiological importance and the development of novel strategies enabling selective modulation of DGK $\alpha$ and $\zeta$ expression and activities for treating autoimmune diseases, viral infections, and cancer.

\section{AUTHOR CONTRIBUTIONS}

$\mathrm{SC}, \mathrm{ZH}$, and $\mathrm{X}-\mathrm{PZ}$ are involved in preparation of the manuscript.

\section{ACKNOWLEDGMENTS}

This work is supported by the National Institutes of Health (R01AI079088 and R01AI101206) for X-PZ.

signaling cascade. FEBS Lett. 531, 65-68. doi: 10.1016/S0014-5793(02) 03483-X

Arumugam, V., Bluemn, T., Wesley, E., Schmidt, A. M., Kambayashi, T., Malarkannan, S., et al. (2015). TCR signaling intensity controls CD8 ${ }^{+} \mathrm{T}$ cell responsiveness to TGF- $\beta$. J. Leukoc. Biol. 98, 703-712. doi: 10.1189/jlb.2HI MA1214-578R

Avila-Flores, A., Santos, T., Rincón, E., and Mérida, I. (2005). Modulation of the mammalian target of rapamycin pathway by diacylglycerol kinaseproduced phosphatidic acid. J. Biol. Chem. 280, 10091-10099. doi: 10.1074/jbc. M412296200

Bachmann, M. F., Wolint, P., Walton, S., Schwarz, K., and Oxenius, A. (2007) Differential role of IL-2R signaling for $\mathrm{CD}^{+} \mathrm{T}$ cell responses in acute and chronic viral infections. Eur. J. Immunol. 37, 1502-1512. doi: 10.1002/eji. 200637023

Baldanzi, G., Pighini, A., Bettio, V., Rainero, E., Traini, S., Chianale, F., et al. (2011). SAP-mediated inhibition of diacylglycerol kinase $\alpha$ regulates TCR-induced diacylglycerol signaling. J. Immunol. 187, 5941-5951. doi: 10.4049/jimmunol.1002476 
Barnes, M. J., Krebs, P., Harris, N., Eidenschenk, C., Gonzalez-Quintial, R., Arnold, C. N., et al. (2009). Commitment to the regulatory $\mathrm{T}$ cell lineage requires CARMA1 in the thymus but not in the periphery. PLoS Biol. 7:e51. doi: 10.1371/journal.pbio.1000051

Becker, T. C., Wherry, E. J., Boone, D., Murali-Krishna, K., Antia, R., Ma, A., et al. (2002). Interleukin 15 is required for proliferative renewal of virus-specific memory CD8 T cells. J. Exp. Med. 195, 1541-1548. doi: 10.1084/jem.20020369

Bendelac, A., Savage, P. B., and Teyton, L. (2007). The biology of NKT cells. Annu. Rev. Immunol. 25, 297-336. doi: 10.1146/annurev.immunol.25.022106.141711

Berzins, S. P., and Ritchie, D. S. (2014). Natural killer T cells: drivers or passengers in preventing human disease? Nat. Rev. Immunol. 14, 640-646. doi: $10.1038 /$ nri3725

Boyman, O., and Sprent, J. (2012). The role of interleukin-2 during homeostasis and activation of the immune system. Nat. Rev. Immunol. 12, 180-190. doi: 10.1038/nri3156

Brennan, P. J., Brigl, M., and Brenner, M. B. (2013). Invariant natural killer T cells: an innate activation scheme linked to diverse effector functions. Nat. Rev. Immunol. 13, 101-117. doi: 10.1038/nri3369

Brose, N., and Rosenmund, C. (2002). Move over protein kinase C, you've got company: alternative cellular effectors of diacylglycerol and phorbol esters. $J$. Cell Sci. 115, 4399-4411. doi: 10.1242/jcs.00122

Cai, J., Abramovici, H., Gee, S. H., and Topham, M. K. (2009). Diacylglycerol kinases as sources of phosphatidic acid. Biochim. Biophys. Acta 1791, 942-948. doi: 10.1016/j.bbalip.2009.02.010

Caloca, M. J., Delgado, P., Alarcón, B., and Bustelo, X. R. (2008). Role of chimaerins, a group of Rac-specific GTPase activating proteins, in T-cell receptor signaling. Cell. Signal. 20, 758-770. doi: 10.1016/j.cellsig.2007.12.015

Caloca, M. J., Garcia-Bermejo, M. L., Blumberg, P. M., Lewin, N. E., Kremmer, E., Mischak, H., et al. (1999). $\beta 2$-chimaerin is a novel target for diacylglycerol: binding properties and changes in subcellular localization mediated by ligand binding to its C1 domain. Proc. Natl. Acad. Sci. U.S.A. 96, 11854-11859. doi: 10.1073/pnas.96.21.11854

Cannons, J. L., Yu, L. J., Hill, B., Mijares, L. A., Dombroski, D., Nichols, K. E., et al. (2004). SAP regulates $\mathrm{T}(\mathrm{H}) 2$ differentiation and PKC- $\theta$-mediated activation of NF-кB1. Immunity 21, 693-706. doi: 10.1016/j.immuni.2004.09.012

Carrasco, S., and Merida, I. (2004). Diacylglycerol-dependent binding recruits PKC $\theta$ and RasGRP1 C1 domains to specific subcellular localizations in living T lymphocytes. Mol. Biol. Cell 15, 2932-2942. doi: 10.1091/mbc.E03-11-0844

Carrio, R., Bathe, O. F., and Malek, T. R. (2004). Initial antigen encounter programs $\mathrm{CD}^{+} \mathrm{T}$ cells competent to develop into memory cells that are activated in an antigen-free, IL-7- and IL-15-rich environment. J. Immunol. 172, 7315-7323. doi: 10.4049/jimmunol.172.12.7315

Chang, P. P., Barral, P., Fitch, J., Pratama, A., Ma, C. S., Kallies, A., et al. (2012). Identification of $\mathrm{Bcl}-6$-dependent follicular helper NKT cells that provide cognate help for B cell responses. Nat. Immunol. 13, 35-43. doi: 10.1038/ni.2166

Chappert, P., and Schwartz, R. H. (2010). Induction of T cell anergy: integration of environmental cues and infectious tolerance. Curr. Opin. Immunol. 22, 552-559. doi: 10.1016/j.coi.2010.08.005

Chauveau, A., Le Floc'h, A., Bantilan, N. S., Koretzky, G. A., and Huse, M. (2014). Diacylglycerol kinase $\alpha$ establishes $\mathrm{T}$ cell polarity by shaping diacylglycerol accumulation at the immunological synapse. Sci. Signal. 7:ra82. doi: $10.1126 /$ scisignal.2005287

Chen, J., and Fang, Y. (2002). A novel pathway regulating the mammalian target of rapamycin (mTOR) signaling. Biochem. Pharmacol. 64, 1071-1077. doi: 10.1016/S0006-2952(02)01263-7

Chen, X., Priatel, J. J., Chow, M. T., and Teh, H. S. (2008). Preferential development of CD4 and CD8 T regulatory cells in RasGRP1-deficient mice. J. Immunol. 180, 5973-5982. doi: 10.4049/jimmunol.180.9.5973

Chen, Y., Ci, X., Gorentla, B., Sullivan, S. A., Stone, J. C., Zhang, W., et al. (2012). Differential requirement of RasGRP1 for $\gamma \delta \mathrm{T}$ cell development and activation. J. Immunol. 189, 61-71. doi: 10.4049/jimmunol.1103272

Chung, B., Aoukaty, A., Dutz, J., Terhorst, C., and Tan, R. (2005). Signaling lymphocytic activation molecule-associated protein controls NKT cell functions. J. Immunol. 174, 3153-3157. doi: 10.4049/jimmunol.174.6.3153

Cichocki, F., Schlums, H., Li, H., Stache, V., Holmes, T., Lenvik, T. R., et al. (2014). Transcriptional regulation of Munc13-4 expression in cytotoxic lymphocytes is disrupted by an intronic mutation associated with a primary immunodeficiency. J. Exp. Med. 211, 1079-1091. doi: 10.1084/jem.20131131
Cockcroft, S. (2009). Phosphatidic acid regulation of phosphatidylinositol 4phosphate 5-kinases. Biochim. Biophys. Acta 1791, 905-912. doi: 10.1016/ j.bbalip.2009.03.007

Constantinides, M. G., and Bendelac, A. (2013). Transcriptional regulation of the NKT cell lineage. Curr. Opin. Immunol. 25, 161-167. doi: 10.1016/j.coi. 2013.01.003

Coquet, J. M., Chakravarti, S., Kyparissoudis, K., Mcnab, F. W., Pitt, L. A., Mckenzie, B. S., et al. (2008). Diverse cytokine production by NKT cell subsets and identification of an IL-17-producing CD4-NK1.1- NKT cell population. Proc. Natl. Acad. Sci. U.S.A. 105, 11287-11292. doi: 10.1073/pnas.0801631105

Cornish, A. L., Chong, M. M., Davey, G. M., Darwiche, R., Nicola, N. A., Hilton, D. J., et al. (2003). Suppressor of cytokine signaling-1 regulates signaling in response to interleukin-2 and other $\gamma \mathrm{c}$-dependent cytokines in peripheral $\mathrm{T}$ cells. J. Biol. Chem. 278, 22755-22761. doi: 10.1074/jbc.M303021200

Crespo, J., Sun, H., Welling, T. H., Tian, Z., and Zou, W. (2013). T cell anergy, exhaustion, senescence, and stemness in the tumor microenvironment. Curr. Opin. Immunol. 25, 214-221. doi: 10.1016/j.coi.2012.12.003

Csaki, L. S., and Reue, K. (2010). Lipins: multifunctional lipid metabolism proteins. Annu. Rev. Nutr. 30, 257-272. doi: 10.1146/annurev.nutr.012809.104729

Cui, G., Staron, M. M., Gray, S. M., Ho, P. C., Amezquita, R. A., Wu, J., et al. (2015). IL-7-Induced Glycerol Transport and TAG Synthesis Promotes Memory CD8 ${ }^{+}$ T Cell Longevity. Cell 161, 750-761. doi: 10.1016/j.cell.2015.03.021

Cui, W., and Kaech, S. M. (2010). Generation of effector CD8 ${ }^{+}$T cells and their conversion to memory $\mathrm{T}$ cells. Immunol. Rev. 236, 151-166. doi: 10.1111/j.1600-065X.2010.00926.x

Delpoux, A., Yakonowsky, P., Durand, A., Charvet, C., Valente, M., Pommier, A., et al. (2014). TCR signaling events are required for maintaining CD4 regulatory $\mathrm{T}$ cell numbers and suppressive capacities in the periphery. J. Immunol. 193, 5914-5923. doi: 10.4049/jimmunol.1400477

Díaz-Flores, E., Siliceo, M., Martínez, A. C., and Mérida, I. (2003). Membrane translocation of protein kinase $\mathrm{C} \theta$ during $\mathrm{T}$ lymphocyte activation requires phospholipase C- $\gamma$-generated diacylglycerol. J. Biol. Chem. 278, 29208-29215. doi: $10.1074 /$ jbc.M303165200

Dower, N. A., Stang, S. L., Bottorff, D. A., Ebinu, J. O., Dickie, P., Ostergaard, H. L., et al. (2000). RasGRP is essential for mouse thymocyte differentiation and TCR signaling. Nat. Immunol. 1, 317-321. doi: 10.1038/80799

Dudda, J. C., Salaun, B., Ji, Y., Palmer, D. C., Monnot, G. C., Merck, E., et al. (2013). MicroRNA-155 is required for effector $\mathrm{CD} 8^{+} \mathrm{T}$ cell responses to virus infection and cancer. Immunity 38, 742-753. doi: 10.1016/j.immuni.2012.12.006

Ebinu, J. O., Bottorff, D. A., Chan, E. Y., Stang, S. L., Dunn, R. J., and Stone, J. C. (1998). RasGRP, a Ras guanyl nucleotide- releasing protein with calcium- and diacylglycerol-binding motifs. Science 280, 1082-1086. doi: $10.1126 /$ science. 280.5366 .1082

Elewaut, D., Shaikh, R. B., Hammond, K. J., De Winter, H., Leishman, A. J., Sidobre, S., et al. (2003). NIK-dependent RelB activation defines a unique signaling pathway for the development of V $\alpha$ 14i NKT cells. J. Exp. Med. 197, 1623-1633. doi: 10.1084/jem.20030141

Fang, X., Wang, R., Ma, J., Ding, Y., Shang, W., and Sun, Z. (2012). Ameliorated ConA-induced hepatitis in the absence of PKC-theta. PLoS ONE 7:e31174. doi: 10.1371/journal.pone.0031174

Fathman, C. G., and Lineberry, N. B. (2007). Molecular mechanisms of CD4 ${ }^{+}$ T-cell anergy. Nat. Rev. Immunol. 7, 599-609. doi: 10.1038/nri2131

Feau, S., Arens, R., Togher, S., and Schoenberger, S. P. (2011). Autocrine IL-2 is required for secondary population expansion of $\mathrm{CD} 8^{+}$memory T cells. Nat. Immunol. 12, 908-913. doi: 10.1038/ni.2079

Feldmann, J., Callebaut, I., Raposo, G., Certain, S., Bacq, D., Dumont, C., et al. (2003). Munc13-4 is essential for cytolytic granules fusion and is mutated in a form of familial hemophagocytic lymphohistiocytosis (FHL3). Cell 115, 461-473. doi: 10.1016/S0092-8674(03)00855-9

Fesnak, A. D., June, C. H., and Levine, B. L. (2016). Engineered T cells: the promise and challenges of cancer immunotherapy. Nat. Rev. Cancer 16, 566-581. doi: $10.1038 /$ nrc. 2016.97

Frank, C., Keilhack, H., Opitz, F., Zschörnig, O., and Böhmer, F. D. (1999). Binding of phosphatidic acid to the protein-tyrosine phosphatase SHP-1 as a basis for activity modulation. Biochemistry 38, 11993-12002. doi: 10.1021/bi9 $82586 \mathrm{w}$

Fuller, D. M., Zhu, M., Song, X., Ou-Yang, C. W., Sullivan, S. A., Stone, J. C., et al. (2012). Regulation of RasGRP1 function in T cell development 
and activation by its unique tail domain. PLOS ONE 7:e38796. doi: 10.1371/journal.pone.0038796

Fulton, R. B., Hamilton, S. E., Xing, Y., Best, J. A., Goldrath, A. W., Hogquist, K. A., et al. (2015). The TCR's sensitivity to self peptide-MHC dictates the ability of naive $\mathrm{CD}^{+} \mathrm{T}$ cells to respond to foreign antigens. Nat. Immunol. 16, 107-117. doi: $10.1038 /$ ni.3043

Galandrini, R., Micucci, F., Tassi, I., Cifone, M. G., Cinque, B., Piccoli, M., et al. (2005). Arf6: a new player in FcgammaRIIIA lymphocyte-mediated cytotoxicity. Blood 106, 577-583. doi: 10.1182/blood-2004-10-4100

Gapin, L., Matsuda, J. L., Surh, C. D., and Kronenberg, M. (2001). NKT cells derive from double-positive thymocytes that are positively selected by CD1d. Nat. Immunol. 2, 971-978. doi: 10.1038/ni710

Gharbi, S. I., Rincon, E., Avila-Flores, A., Torres-Ayuso, P., Almena, M., Cobos, M. A., et al. (2011). Diacylglycerol kinase $\zeta$ controls diacylglycerol metabolism at the immunological synapse. Mol. Biol. Cell 22, 4406-4414. doi: 10.1091/mbc.E11-03-0247

Ghosh, S., Strum, J. C., Sciorra, V. A., Daniel, L., and Bell, R. M. (1996). Raf-1 kinase possesses distinct binding domains for phosphatidylserine and phosphatidic acid. Phosphatidic acid regulates the translocation of Raf-1 in 12O-tetradecanoylphorbol-13-acetate-stimulated Madin-Darby canine kidney cells. J. Biol. Chem. 271, 8472-8480. doi: 10.1074/jbc.271.14.8472

Godfrey, D. I., Stankovic, S., and Baxter, A. G. (2010). Raising the NKT cell family. Nat. Immunol. 11, 197-206. doi: 10.1038/ni.1841

Golec, D. P., Henao Caviedes, L. M., and Baldwin, T. A. (2016). RasGRP1 and RasGRP3 Are required for efficient generation of early thymic progenitors. J. Immunol. 197, 1743-1753. doi: 10.4049/jimmunol.1502107

Gorentla, B. K., Krishna, S., Shin, J., Inoue, M., Shinohara, M. L., Grayson, J. M., et al. (2013). Mnk1 and 2 are dispensable for T cell development and activation but important for the pathogenesis of experimental autoimmune encephalomyelitis. J. Immunol. 190, 1026-1037. doi: 10.4049/jimmunol. 1200026

Gorentla, B. K., Wan, C. K., and Zhong, X. P. (2011). Negative regulation of mTOR activation by diacylglycerol kinases. Blood 117, 4022-4031. doi: 10.1182/blood2010-08-300731

Gracias, D. T., Stelekati, E., Hope, J. L., Boesteanu, A. C., Doering, T. A., Norton, J., et al. (2013). The microRNA miR-155 controls $\mathrm{CD}^{+} \mathrm{T}$ cell responses by regulating interferon signaling. Nat. Immunol. 14, 593-602. doi: 10.1038/ ni. 2576

Griewank, K., Borowski, C., Rietdijk, S., Wang, N., Julien, A., Wei, D. G., et al. (2007). Homotypic interactions mediated by Slamf1 and Slamf6 receptors control NKT cell lineage development. Immunity 27, 751-762. doi: 10.1016/ j.immuni.2007.08.020

Guo, R., Wan, C. K., Carpenter, J. H., Mousallem, T., Boustany, R. M., Kuan, C. T., et al. (2008). Synergistic control of T cell development and tumor suppression by diacylglycerol kinase $\alpha$ and $\zeta$. Proc. Natl. Acad. Sci. U.S.A. 105, 11909-11914. doi: 10.1073/pnas.0711856105

Gupta, S., Manicassamy, S., Vasu, C., Kumar, A., Shang, W., and Sun, Z. (2008). Differential requirement of $\mathrm{PKC}-\theta$ in the development and function of natural regulatory $\mathrm{T}$ cells. Mol. Immunol. 46, 213-224. doi: 10.1016/j.molimm.2008.08.275

Hamilton, K. S., Phong, B., Corey, C., Cheng, J., Gorentla, B., Zhong, X., et al. (2014). T cell receptor-dependent activation of mTOR signaling in T cells is mediated by Carma1 and MALT1, but not Bcl10. Sci. Signal. 7:ra55. doi: 10.1126/scisignal.2005169

Harty, J. T., and Badovinac, V. P. (2008). Shaping and reshaping CD8 ${ }^{+}$T-cell memory. Nat. Rev. Immunol. 8, 107-119. doi: 10.1038/nri2251

Hayashi, K., and Altman, A. (2007). Protein kinase C theta (PKC $\theta)$ : a key player in T cell life and death. Pharmacol. Res. 55, 537-544. doi: 10.1016/j.phrs. 2007.04.009

Hu, T., Gimferrer, I., Simmons, A., Wiest, D., and Alberola-Ila, J. (2011). The Ras/MAPK pathway is required for generation of iNKT cells. PLoS ONE 6:e19890. doi: 10.1371/journal.pone.0019890

Iborra, S., Ramos, M., Arana, D. M., Lazaro, S., Aguilar, F., Santos, E., et al. (2013). $\mathrm{N}$-ras couples antigen receptor signaling to Eomesodermin and to functional $\mathrm{CD}^{+}{ }^{+} \mathrm{T}$ cell memory but not to effector differentiation. J. Exp. Med. 210, 1463-1479. doi: 10.1084/jem.20112495

Isakov, N., and Altman, A. (2002). protein kinase $\mathrm{c} \theta$ in T cell activation. Annu. Rev. Immunol. 20, 761-794. doi: 10.1146/annurev.immunol.20.100301.064807
Jarquin-Pardo, M., Fitzpatrick, A., Galiano, F. J., First, E. A., and Davis, J. N. (2007). Phosphatidic acid regulates the affinity of the murine phosphatidylinositol 4-phosphate 5-kinase-I $\beta$ for phosphatidylinositol-4phosphate. J. Cell. Biochem. 100, 112-128. doi: 10.1002/jcb.21027

Jenkins, G. M., and Frohman, M. A. (2005). Phospholipase D: a lipid centric review. Cell. Mol. Life Sci. 62, 2305-2316. doi: 10.1007/s00018-005-5195-Z

Johnson, J. L., Hong, H., Monfregola, J., Kiosses, W. B., and Catz, S. D. (2011). Munc13-4 restricts motility of Rab27a-expressing vesicles to facilitate lipopolysaccharide-induced priming of exocytosis in neutrophils. J. Biol. Chem. 286, 5647-5656. doi: 10.1074/jbc.M110.184762

Jones, D. R., Sanjuan, M. A., Stone, J. C., and Merida, I. (2002). Expression of a catalytically inactive form of diacylglycerol kinase $\alpha$ induces sustained signaling through RasGRP. FASEB J. 16, 595-597. doi: 10.1096/fj.01-0762fje

Joshi, R. P., Schmidt, A. M., Das, J., Pytel, D., Riese, M. J., Lester, M., et al. (2013). The $\zeta$ isoform of diacylglycerol kinase plays a predominant role in regulatory $\mathrm{T}$ cell development and TCR-mediated ras signaling. Sci. Signal. 6:ra102. doi: 10.1126/scisignal.2004373

Kaech, S. M., Tan, J. T., Wherry, E. J., Konieczny, B. T., Surh, C. D., and Ahmed, R. (2003). Selective expression of the interleukin 7 receptor identifies effector CD8 $\mathrm{T}$ cells that give rise to long-lived memory cells. Nat. Immunol. 4, 1191-1198. doi: 10.1038/ni1009

Kai, M., Yasuda, S., Imai, S., Toyota, M., Kanoh, H., and Sakane, F. (2009). Diacylglycerol kinase $\alpha$ enhances protein kinase $C \zeta$-dependent phosphorylation at Ser311 of p65/RelA subunit of nuclear factor-кB. FEBS Lett. 583, 3265-3268. doi: 10.1016/j.febslet.2009.09.017

Kalekar, L. A., Schmiel, S. E., Nandiwada, S. L., Lam, W. Y., Barsness, L. O., Zhang, N., et al. (2016). CD4 ${ }^{+} \mathrm{T}$ cell anergy prevents autoimmunity and generates regulatory T cell precursors. Nat. Immunol. 17, 304-314. doi: 10.1038/ni.3331

Kawano, T., Cui, J., Koezuka, Y., Toura, I., Kaneko, Y., Motoki, K., et al. (1997). CD1d-restricted and TCR-mediated activation of $\mathrm{V}_{\alpha} 14$ NKT cells by glycosylceramides. Science 278, 1626-1629. doi: 10.1126/science.278.53 43.1626

Kieper, W. C., Tan, J. T., Bondi-Boyd, B., Gapin, L., Sprent, J., Ceredig, R., et al. (2002). Overexpression of interleukin (IL)-7 leads to IL-15-independent generation of memory phenotype $\mathrm{CD}^{+}$T cells. J. Exp. Med. 195, 1533-1539. doi: 10.1084 /jem.20020067

Kim, J. K., Klinger, M., Benjamin, J., Xiao, Y., Erle, D. J., Littman, D. R., et al. (2009). Impact of the TCR signal on regulatory T cell homeostasis, function, and trafficking. PLoS ONE 4:e6580. doi: 10.1371/journal.pone.0006580

Koch, H., Hofmann, K., and Brose, N. (2000). Definition of Munc13-homologydomains and characterization of a novel ubiquitously expressed Munc13 isoform. Biochem. J. 349, 247-253. doi: 10.1042/bj3490247

Kraft, C. A., Garrido, J. L., Fluharty, E., Leiva-Vega, L., and Romero, G. (2008). Role of phosphatidic acid in the coupling of the ERK cascade. J. Biol. Chem. 283, 36636-36645. doi: 10.1074/jbc.M804633200

Krishna, S., Xie, D., Gorentla, B., Shin, J., Gao, J., and Zhong, X. P. (2012). Chronic activation of the kinase IKK $\beta$ impairs T cell function and survival. J. Immunol. 189, 1209-1219. doi: 10.4049/jimmunol.1102429

Krishna, S., and Zhong, X. (2013a). Role of diacylglycerol kinases in T cell development and function. Crit. Rev. Immunol. 33, 97-118.

Krishna, S., and Zhong, X. P. (2013b). Regulation of lipid signaling by diacylglycerol kinases during $\mathrm{T}$ cell development and function. Front. Immunol. 4:178. doi: 10.3389/fimmu.2013.00178

Kwon, M. J., Ma, J., Ding, Y., Wang, R., and Sun, Z. (2012). Protein kinase C$\theta$ promotes Th17 differentiation via upregulation of Stat3. J. Immunol. 188, 5887-5897. doi: 10.4049/jimmunol.1102941

Lee, Y. J., Holzapfel, K. L., Zhu, J., Jameson, S. C., and Hogquist, K. A. (2013). Steady-state production of IL-4 modulates immunity in mouse strains and is determined by lineage diversity of iNKT cells. Nat. Immunol. 14, 1146-1154. doi: $10.1038 /$ ni.2731

Levine, A. G., Arvey, A., Jin, W., and Rudensky, A. Y. (2014). Continuous requirement for the TCR in regulatory $\mathrm{T}$ cell function. Nat. Immunol. 15, 1070-1078. doi: 10.1038/ni.3004

Li, M. O., and Rudensky, A. Y. (2016). T cell receptor signalling in the control of regulatory T cell differentiation and function. Nat. Rev. Immunol. 16, 220-233. doi: $10.1038 /$ nri.2016.26

Liu, C. H., Machado, F. S., Guo, R., Nichols, K. E., Burks, A. W., Aliberti J. C., et al. (2007). Diacylglycerol kinase $\zeta$ regulates microbial recognition 
and host resistance to Toxoplasma gondii. J. Exp. Med. 204, 781-792. doi: 10.1084/jem.20061856

Lynch, L., Michelet, X., Zhang, S., Brennan, P. J., Moseman, A., Lester, C., et al. (2015). Regulatory iNKT cells lack expression of the transcription factor PLZF and control the homeostasis of T(reg) cells and macrophages in adipose tissue. Nat. Immunol. 16, 85-95. doi: 10.1038/ni.3047

Macian, F., Garcia-Cozar, F., Im, S. H., Horton, H. F., Byrne, M. C., and Rao, A. (2002). Transcriptional mechanisms underlying lymphocyte tolerance. Cell 109, 719-731. doi: 10.1016/S0092-8674(02)00767-5

Mahmud, S. A., Manlove, L. S., Schmitz, H. M., Xing, Y., Wang, Y., Owen, D. L., et al. (2014). Costimulation via the tumor-necrosis factor receptor superfamily couples TCR signal strength to the thymic differentiation of regulatory T cells. Nat. Immunol. 15, 473-481. doi: 10.1038/ni.2849

Manicassamy, S., Gupta, S., Huang, Z., and Sun, Z. (2006). Protein kinase C$\theta$-mediated signals enhance $\mathrm{CD}^{+}{ }^{+} \mathrm{T}$ cell survival by up-regulating Bcl-xL. J. Immunol. 176, 6709-6716. doi: 10.4049/jimmunol.176.11.6709

Marchingo, J. M., Kan, A., Sutherland, R. M., Duffy, K. R., Wellard, C. J., Belz, G. T., et al. (2014). T cell signaling. Antigen affinity, costimulation, and cytokine inputs sum linearly to amplify $\mathrm{T}$ cell expansion. Science 346, 1123-1127. doi: $10.1126 /$ science. 1260044

Marklund, U., Lightfoot, K., and Cantrell, D. (2003). Intracellular location and cell context-dependent function of protein kinase D. Immunity 19, 491-501. doi: 10.1016/S1074-7613(03)00260-7

Marsland, B. J., Soos, T. J., Spath, G., Littman, D. R., and Kopf, M. (2004). Protein kinase $\mathrm{C} \theta$ is critical for the development of in vivo $\mathrm{T}$ helper (Th)2 cell but not Th1 cell responses. J. Exp. Med. 200, 181-189. doi: 10.1084/jem.20032229

Martinez-Moreno, M., Garcia-Lievana, J., Soutar, D., Torres-Ayuso, P., Andrada, E., Zhong, X. P., et al. (2012). FoxO-dependent regulation of diacylglycerol kinase $\alpha$ gene expression. Mol. Cell. Biol. 32, 4168-4180. doi: 10.1128/MCB.00654-12

Matsuda, Y., Toda, M., Kato, T., Kuribayashi, K., and Kakimi, K. (2006). Fulminant liver failure triggered by therapeutic antibody treatment in a mouse model. Int. J. Oncol. 29, 1119-1125. doi: 10.3892/ijo.29.5.1119

Medoff, B. D., Sandall, B. P., Landry, A., Nagahama, K., Mizoguchi, A., Luster, A. D., et al. (2009). Differential requirement for CARMA1 in agonistselected T-cell development. Eur. J. Immunol. 39, 78-84. doi: 10.1002/eji.2008 38734

Menager, M. M., Menasche, G., Romao, M., Knapnougel, P., Ho, C. H., Garfa, M., et al. (2007). Secretory cytotoxic granule maturation and exocytosis require the effector protein hMunc13-4. Nat. Immunol. 8, 257-267. doi: 10.1038/ni1431

Mendiratta, S. K., Martin, W. D., Hong, S., Boesteanu, A., Joyce, S., and Van Kaer, L. (1997). CD1d1 mutant mice are deficient in natural T cells that promptly produce IL-4. Immunity 6, 469-477. doi: 10.1016/S1074-7613(00)80290-3

Merida, I., Andrada, E., Gharbi, S. I., and Avila-Flores, A. (2015). Redundant and specialized roles for diacylglycerol kinases $\alpha$ and $\zeta$ in the control of $\mathrm{T}$ cell functions. Sci. Signal. 8:re6. doi: 10.1126/scisignal.aaa0974

Merida, I., Avila-Flores, A., and Merino, E. (2008). Diacylglycerol kinases: at the hub of cell signalling. Biochem. J. 409, 1-18. doi: 10.1042/BJ20071040

Metzger, T. C., and Anderson, M. S. (2011). Control of central and peripheral tolerance by Aire. Immunol. Rev. 241, 89-103. doi: 10.1111/j.1600065X.2011.01008.x

Michel, M. L., Keller, A. C., Paget, C., Fujio, M., Trottein, F., Savage, P. B., et al. (2007). Identification of an IL-17-producing NK1.1(neg) iNKT cell population involved in airway neutrophilia. J. Exp. Med. 204, 995-1001. doi: 10.1084/jem.20061551

Michel, M. L., Mendes-Da-Cruz, D., Keller, A. C., Lochner, M., Schneider, E., Dy, M., et al. (2008). Critical role of ROR-gammat in a new thymic pathway leading to IL-17-producing invariant NKT cell differentiation. Proc. Natl. Acad. Sci. U.S.A. 105, 19845-19850. doi: 10.1073/pnas.0806472105

Micucci, F., Capuano, C., Marchetti, E., Piccoli, M., Frati, L., Santoni, A., et al. (2008). PI5KI-dependent signals are critical regulators of the cytolytic secretory pathway. Blood 111, 4165-4172. doi: 10.1182/blood-2007-08-108886

Milpied, P., Massot, B., Renand, A., Diem, S., Herbelin, A., Leite-De-Moraes, M., et al. (2011). IL-17-producing invariant NKT cells in lymphoid organs are recent thymic emigrants identified by neuropilin-1 expression. Blood 118, 2993-3002. doi: 10.1182/blood-2011-01-329268

Monfregola, J., Johnson, J. L., Meijler, M. M., Napolitano, G., and Catz, S. D. (2012). MUNC13-4 protein regulates the oxidative response and is essential for phagosomal maturation and bacterial killing in neutrophils. J. Biol. Chem. 287, 44603-44618. doi: 10.1074/jbc.M112.414029

Moon, E. K., Wang, L. C., Dolfi, D. V., Wilson, C. B., Ranganathan, R., Sun, J., et al. (2014). Multifactorial T-cell hypofunction that is reversible can limit the efficacy of chimeric antigen receptor-transduced human T cells in solid tumors. Clin. Cancer Res. 20, 4262-4273. doi: 10.1158/1078-0432.CCR-13-2627

Morrison, D. K. (2001). KSR: a MAPK scaffold of the Ras pathway? J. Cell Sci. 114, 1609-1612.

Navarro, M. N., Feijoo-Carnero, C., Arandilla, A. G., Trost, M., and Cantrell, D. A. (2014). Protein kinase D2 is a digital amplifier of T cell receptorstimulated diacylglycerol signaling in naive CD8 ${ }^{+}$T cells. Sci. Signal. 7:ra99. doi: 10.1126/scisignal.2005477

Nichols, K. E., Hom, J., Gong, S. Y., Ganguly, A., Ma, C. S., Cannons, J. L., et al. (2005). Regulation of NKT cell development by SAP, the protein defective in XLP. Nat. Med. 11, 340-345. doi: 10.1038/nm1189

Olenchock, B. A., Guo, R., Carpenter, J. H., Jordan, M., Topham, M. K., Koretzky, G. A., et al. (2006a). Disruption of diacylglycerol metabolism impairs the induction of T cell anergy. Nat. Immunol. 7, 1174-1181. doi: 10.1038/ni1400

Olenchock, B. A., Guo, R., Silverman, M. A., Wu, J. N., Carpenter, J. H., Koretzky, G. A., et al. (2006b). Impaired degranulation but enhanced cytokine production after Fc $\varepsilon$ RI stimulation of diacylglycerol kinase $\zeta$-deficient mast cells. J. Exp. Med. 203, 1471-1480. doi: 10.1084/jem.20052424

Osman, Y., Kawamura, T., Naito, T., Takeda, K., Van Kaer, L., Okumura, K., et al. (2000). Activation of hepatic NKT cells and subsequent liver injury following administration of $\alpha$-galactosylceramide. Eur. J. Immunol. 30, 1919-1928. doi: 10.1002/1521-4141(200007)30:7\&\#60;1919::AID-IMMU1919\&\#62;3.0.CO;2-3

Outram, S. V., Crompton, T., Merida, I., Varas, A., and Martinez, A. C. (2002). Diacylglycerol kinase $\alpha$ activity promotes survival of $\mathrm{CD} 4{ }^{+} \mathrm{CD} 8^{+}$double positive cells during thymocyte development. Immunology 105, 391-398. doi: 10.1046/j.1365-2567.2002.01385.x

Pasquier, B., Yin, L., Fondaneche, M. C., Relouzat, F., Bloch-Queyrat, C., Lambert, N., et al. (2005). Defective NKT cell development in mice and humans lacking the adapter SAP, the X-linked lymphoproliferative syndrome gene product. J. Exp. Med. 201, 695-701. doi: 10.1084/jem.20042432

Powell, J. D. (2006). The induction and maintenance of T cell anergy. Clin. Immunol. 120, 239-246. doi: 10.1016/j.clim.2006.02.004

Prevot, N., Pyaram, K., Bischoff, E., Sen, J. M., Powell, J. D., and Chang, C. H. (2015). Mammalian target of rapamycin complex 2 regulates invariant NKT cell development and function independent of promyelocytic leukemia zinc-finger. J. Immunol. 194, 223-230. doi: 10.4049/jimmunol.1401985

Priatel, J. J., Chen, X., Huang, Y. H., Chow, M. T., Zenewicz, L. A., Coughlin, J. J., et al. (2010). RasGRP1 regulates antigen-induced developmental programming by naive CD8 $\mathrm{T}$ cells. J. Immunol. 184, 666-676. doi: 10.4049/jimmunol.0803521

Priatel, J. J., Teh, S. J., Dower, N. A., Stone, J. C., and Teh, H. S. (2002). RasGRP1 transduces low-grade TCR signals which are critical for $\mathrm{T}$ cell development, homeostasis, and differentiation. Immunity 17, 617-627. doi: 10.1016/S10747613(02)00451-X

Rampuria, P., and Lang, M. L. (2015). CD1d-dependent expansion of NKT follicular helper cells in vivo and in vitro is a product of cellular proliferation and differentiation. Int. Immunol. 27, 253-263. doi: 10.1093/intimm/dxv007

Riese, M. J., Grewal, J., Das, J., Zou, T., Patil, V., Chakraborty, A. K., et al. (2011). Decreased diacylglycerol metabolism enhances ERK activation and augments CD8+ T cell functional responses. J. Biol. Chem. 286, 5254-5265. doi: 10.1074/jbc.M110.171884

Riese, M. J., Wang, L. C., Moon, E. K., Joshi, R. P., Ranganathan, A., June, C. H., et al. (2013). Enhanced effector responses in activated CD8 $+\mathrm{T}$ cells deficient in diacylglycerol kinases. Cancer Res. 73, 3566-3577. doi: 10.1158/00085472.CAN-12-3874

Rizzo, M. A., Shome, K., Vasudevan, C., Stolz, D. B., Sung, T. C., Frohman, M. A., et al. (1999). Phospholipase D and its product, phosphatidic acid, mediate agonist-dependent raf-1 translocation to the plasma membrane and the activation of the mitogen-activated protein kinase pathway. J. Biol. Chem. 274, 1131-1139. doi: 10.1074/jbc.274.2.1131

Rizzo, M. A., Shome, K., Watkins, S. C., and Romero, G. (2000). The recruitment of Raf-1 to membranes is mediated by direct interaction with phosphatidic acid and is independent of association with Ras. J. Biol. Chem. 275, 23911-23918. doi: 10.1074/jbc.M001553200 
Roose, J. P., Mollenauer, M., Gupta, V. A., Stone, J., and Weiss, A. (2005). A diacylglycerol-protein kinase C-RasGRP1 pathway directs Ras activation upon antigen receptor stimulation of T cells. Mol. Cell. Biol. 25, 4426-4441. doi: 10.1128/MCB.25.11.4426-4441.2005

Rozengurt, E., Rey, O., and Waldron, R. T. (2005). Protein kinase D signaling. J. Biol. Chem. 280, 13205-13208. doi: 10.1074/jbc.R500002200

Ruffo, E., Malacarne, V., Larsen, S. E., Das, R., Patrussi, L., Wulfing, C., et al. (2016). Inhibition of diacylglycerol kinase $\alpha$ restores restimulation-induced cell death and reduces immunopathology in XLP-1. Sci. Transl. Med. 8:321ra327. doi: 10.1126/scitranslmed.aad1565

Sag, D., Krause, P., Hedrick, C. C., Kronenberg, M., and Wingender, G. (2014). IL10-producing NKT10 cells are a distinct regulatory invariant NKT cell subset. J. Clin. Invest. 124, 3725-3740. doi: 10.1172/JCI72308

Sakane, F., Imai, S., Kai, M., Yasuda, S., and Kanoh, H. (2007). Diacylglycerol kinases: why so many of them? Biochim. Biophys. Acta 1771, 793-806. doi: 10.1016/j.bbalip.2007.04.006

Salio, M., Silk, J. D., Jones, E. Y., and Cerundolo, V. (2014). Biology of CD1- and MR1-restricted T cells. Annu. Rev. Immunol. 32, 323-366. doi: 10.1146/annurev-immunol-032713-120243

Sandau, M. M., Kohlmeier, J. E., Woodland, D. L., and Jameson, S. C. (2010). IL-15 regulates both quantitative and qualitative features of the memory CD8 T cell pool. J. Immunol. 184, 35-44. doi: 10.4049/jimmunol.0803355

Sanjuan, M. A., Pradet-Balade, B., Jones, D. R., Martinez, A. C., Stone, J. C., GarciaSanz, J. A., et al. (2003). T cell activation in vivo targets diacylglycerol kinase $\alpha$ to the membrane: a novel mechanism for Ras attenuation. J. Immunol. 170, 2877-2883. doi: 10.4049/jimmunol.170.6.2877

Sarkar, S., Kalia, V., Haining, W. N., Konieczny, B. T., Subramaniam, S., and Ahmed, R. (2008). Functional and genomic profiling of effector CD8 T cell subsets with distinct memory fates. J. Exp. Med. 205, 625-640. doi: 10.1084/ jem.20071641

Schmidt, A. M., Lu, W., Sindhava, V. J., Huang, Y., Burkhardt, J. K., Yang, E., et al. (2015). Regulatory T cells require TCR signaling for their suppressive function. J. Immunol. 194, 4362-4370. doi: 10.4049/jimmunol.1402384

Schmidt, A. M., Zou, T., Joshi, R. P., Leichner, T. M., Pimentel, M. A., Sommers, C. L., et al. (2013). Diacylglycerol kinase $\zeta$ limits the generation of natural regulatory T cells. Sci. Signal. 6:ra101. doi: 10.1126/scisignal.2004411

Schmidt-Supprian, M., Tian, J., Grant, E. P., Pasparakis, M., Maehr, R., Ovaa, H., et al. (2004). Differential dependence of $\mathrm{CD}^{+} \mathrm{CD} 25^{+}$regulatory and natural killer-like T cells on signals leading to NF-кB activation. Proc. Natl. Acad. Sci. U.S.A. 101, 4566-4571. doi: 10.1073/pnas.0400885101

Schwartz, R. H. (2003). T cell anergy. Annu. Rev. Immunol. 21, 305-334. doi: 10.1146/annurev.immunol.21.120601.141110

Shen, S., Chen, Y., Gorentla, B. K., Lu, J., Stone, J. C., and Zhong, X. P. (2011a). Critical roles of RasGRP1 for invariant NKT cell development. J. Immunol. 187, 4467-4473. doi: 10.4049/jimmunol.1003798

Shen, S., Wu, J., Srivatsan, S., Gorentla, B. K., Shin, J., Xu, L., et al. (2011b). Tight regulation of diacylglycerol-mediated signaling is critical for proper invariant NKT cell development. J. Immunol. 187, 2122-2129. doi: 10.4049/ jimmunol.1100495

Shin, J., O’brien, T. F., Grayson, J. M., and Zhong, X. P. (2012). Differential regulation of primary and memory CD8 $\mathrm{T}$ cell immune responses by diacylglycerol kinases. J. Immunol. 188, 2111-2117. doi: 10.4049/ jimmunol.1102265

Shin, J., Wang, S., Deng, W., Wu, J., Gao, J., and Zhong, X. P. (2014). Mechanistic target of rapamycin complex 1 is critical for invariant natural killer T-cell development and effector function. Proc. Natl. Acad. Sci. U.S.A. 111, E776E783. doi: 10.1073/pnas.1315435111

Shin, J., Xie, D., and Zhong, X. P. (2013a). MicroRNA-34a enhances T cell activation by targeting diacylglycerol kinase $\zeta$. PLOS ONE 8:e77983. doi: 10.1371/journal.pone.0077983

Shin, J., Zhang, P., Wang, S., Wu, J., Guan, Z., and Zhong, X. P. (2013b). Negative control of mast cell degranulation and the anaphylactic response by the phosphatase lipin1. Eur. J. Immunol. 43, 240-248. doi: 10.1002/eji.201242571

Shirakawa, R., Higashi, T., Tabuchi, A., Yoshioka, A., Nishioka, H., Fukuda, M., et al. (2004). Munc13-4 is a GTP-Rab27-binding protein regulating dense core granule secretion in platelets. J. Biol. Chem. 279, 10730-10737. doi: 10.1074/jbc.M309426200
Shome, K., Vasudevan, C., and Romero, G. (1997). ARF proteins mediate insulin-dependent activation of phospholipase D. Curr. Biol. 7, 387-396. doi: 10.1016/S0960-9822(06)00186-2

Siliceo, M., Garcia-Bernal, D., Carrasco, S., Diaz-Flores, E., Coluccio Leskow, F., Teixido, J., et al. (2006). $\beta 2$-chimaerin provides a diacylglycerol-dependent mechanism for regulation of adhesion and chemotaxis of T cells. J. Cell Sci. 119, 141-152. doi: 10.1242/jcs.02722

Siliceo, M., and Merida, I. (2009). T cell receptor-dependent tyrosine phosphorylation of $\beta 2$-chimaerin modulates its Rac-GAP function in $T$ cells. J. Biol. Chem. 284, 11354-11363. doi: 10.1074/jbc.M806098200

Sivakumar, V., Hammond, K. J., Howells, N., Pfeffer, K., and Weih, F. (2003). Differential requirement for Rel/nuclear factor $\kappa \mathrm{B}$ family members in natural killer T cell development. J. Exp. Med. 197, 1613-1621. doi: 10.1084/jem.20022234

Spitaler, M., Emslie, E., Wood, C. D., and Cantrell, D. (2006). Diacylglycerol and protein kinase D localization during T lymphocyte activation. Immunity 24, 535-546. doi: 10.1016/j.immuni.2006.02.013

Stanic, A. K., Bezbradica, J. S., Park, J. J., Van Kaer, L., Boothby, M. R., and Joyce, S. (2004). Cutting edge: the ontogeny and function of Va14Ja18 natural

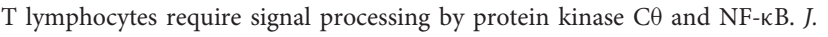
Immunol. 172, 4667-4671. doi: 10.4049/jimmunol.172.8.4667

Starbeck-Miller, G. R., Xue, H. H., and Harty, J. T. (2014). IL-12 and type I interferon prolong the division of activated CD8 $\mathrm{T}$ cells by maintaining high-affinity IL-2 signaling in vivo. J. Exp. Med. 211, 105-120. doi: 10.1084/jem.20130901

Sun, Z., Arendt, C. W., Ellmeier, W., Schaeffer, E. M., Sunshine, M. J., Gandhi, L., et al. (2000). PKC- $\theta$ is required for TCR-induced NF- $\mathrm{B}$ activation in mature but not immature T lymphocytes. Nature 404, 402-407. doi: 10.1038/35006090

Terashima, A., Watarai, H., Inoue, S., Sekine, E., Nakagawa, R., Hase, K., et al. (2008). A novel subset of mouse NKT cells bearing the IL-17 receptor B responds to IL-25 and contributes to airway hyperreactivity. J. Exp. Med. 205, 2727-2733. doi: 10.1084/jem.20080698

Tonti, E., Fedeli, M., Napolitano, A., Iannacone, M., Von Andrian, U. H., Guidotti, L. G., et al. (2012). Follicular helper NKT cells induce limited B cell responses and germinal center formation in the absence of $\mathrm{CD}^{+} \mathrm{T}$ cell help. J. Immunol. 188, 3217-3222. doi: 10.4049/jimmunol.1103501

Tsuchiya, R., Tanaka, T., Hozumi, Y., Nakano, T., Okada, M., Topham, M. K., et al. (2015). Downregulation of diacylglycerol kinase $\zeta$ enhances activation of cytokine-induced NF-кB signaling pathway. Biochim. Biophys. Acta 1853, 361-369. doi: 10.1016/j.bbamcr.2014.11.011

Vahl, J. C., Drees, C., Heger, K., Heink, S., Fischer, J. C., Nedjic, J., et al. (2014). Continuous $\mathrm{T}$ cell receptor signals maintain a functional regulatory $\mathrm{T}$ cell pool. Immunity 41, 722-736. doi: 10.1016/j.immuni.2014.10.012

Van Der Windt, G. J., Everts, B., Chang, C. H., Curtis, J. D., Freitas, T. C., Amiel, E., et al. (2012). Mitochondrial respiratory capacity is a critical regulator of $\mathrm{CD}^{+} \mathrm{T}$ cell memory development. Immunity 36, 68-78. doi: 10.1016/j.immuni.2011.12.007

Van Kaer, L., Parekh, V. V., and Wu, L. (2013). Invariant natural killer T cells as sensors and managers of inflammation. Trends Immunol. 34, 50-58. doi: 10.1016/j.it.2012.08.009

Wang, X., Devaiah, S. P., Zhang, W., and Welti, R. (2006). Signaling functions of phosphatidic acid. Prog. Lipid Res. 45, 250-278. doi: 10.1016/j.plipres.2006.01.005

Watarai, H., Sekine-Kondo, E., Shigeura, T., Motomura, Y., Yasuda, T., Satoh, R., et al. (2012). Development and function of invariant natural killer $\mathrm{T}$ cells producing $\mathrm{T}(\mathrm{h}) 2$ - and $\mathrm{T}(\mathrm{h}) 17$-cytokines. PLoS Biol. 10:e1001255. doi: 10.1371/journal.pbio.1001255

Wei, J., Yang, K., and Chi, H. (2014). Cutting edge: discrete functions of mTOR signaling in invariant NKT cell development and NKT17 fate decision. J. Immunol. 193, 4297-4301. doi: 10.4049/jimmunol.1402042

Werlen, G., Jacinto, E., Xia, Y., and Karin, M. (1998). Calcineurin preferentially synergizes with PKC- $\theta$ to activate JNK and IL-2 promoter in T lymphocytes. EMBO J. 17, 3101-3111. doi: 10.1093/emboj/17.11.3101

Wheeler, M. L., Dong, M. B., Brink, R., Zhong, X. P., and Defranco, A. L. (2013). Diacylglycerol kinase $\zeta$ limits B cell antigen receptor-dependent activation of ERK signaling to inhibit early antibody responses. Sci. Signal. 6, ra91. doi: 10.1126/scisignal.2004189 
Williams, M. A., Holmes, B. J., Sun, J. C., and Bevan, M. J. (2006). Developing and maintaining protective $\mathrm{CD}^{+}$memory T cells. Immunol. Rev. 211, 146-153. doi: 10.1111/j.0105-2896.2006.00389.x

Willoughby, J. E., Costello, P. S., Nicolas, R. H., Robinson, N. J., Stamp, G., Powrie, F., et al. (2007). Raf signaling but not the ERK effector SAP-1 is required for regulatory $\mathrm{T}$ cell development. J. Immunol. 179, 6836-6844. doi: 10.4049/jimmunol.179.10.6836

Winter, J. N., Fox, T. E., Kester, M., Jefferson, L. S., and Kimball, S. R. (2010). Phosphatidic acid mediates activation of mTORC1 through the ERK signaling pathway. Am. J. Physiol. Cell Physiol. 299, C335-C344. doi: 10.1152/ajpcell.00039.2010

Wu, J., Shen, S., Yang, J., Xia, Z., and Zhong, X. P. (2013). Diacylglycerol kinase zeta positively controls the development of iNKT-17 cells. PLoS ONE 8:e75202. doi: 10.1371/journal.pone.0075202

Wu, J., Shin, J., Xie, D., Wang, H., Gao, J., and Zhong, X. P. (2014a). Tuberous sclerosis 1 promotes invariant NKT cell anergy and inhibits invariant NKT cell-mediated antitumor immunity. J. Immunol. 192, 2643-2650. doi: 10.4049/jimmunol.1302076

Wu, J., Yang, J., Yang, K., Wang, H., Gorentla, B., Shin, J., et al. (2014b). iNKT cells require TSC1 for terminal maturation and effector lineage fate decisions. J. Clin. Invest. 124, 1685-1698. doi: 10.1172/JCI69780

Wu, Y., Borde, M., Heissmeyer, V., Feuerer, M., Lapan, A. D., Stroud, J. C., et al. (2006). FOXP3 controls regulatory T cell function through cooperation with NFAT. Cell 126, 375-387. doi: 10.1016/j.cell.2006.05.042

Xie, D. L., Wu, J., Lou, Y. L., and Zhong, X. P. (2012). Tumor suppressor TSC1 is critical for T-cell anergy. Proc. Natl. Acad. Sci. U.S.A. 109, 14152-14157. doi: 10.1073/pnas.1119744109

Xing, Y., and Hogquist, K. A. (2012). T-cell tolerance: central and peripheral. Cold Spring Harb. Perspect. Biol. 4, 1-15. doi: 10.1101/cshperspect.a006957

Yanagisawa, K., Yasuda, S., Kai, M., Imai, S., Yamada, K., Yamashita, T., et al. (2007). Diacylglycerol kinase $\alpha$ suppresses tumor necrosis factor-alpha-induced apoptosis of human melanoma cells through NF-кB activation. Biochim. Biophys. Acta 1771, 462-474. doi: 10.1016/j.bbalip.2006.12.008

Yang, C., and Kazanietz, M. G. (2007). Chimaerins: GAPs that bridge diacylglycerol signalling and the small G-protein Rac. Biochem. J. 403, 1-12. doi: 10.1042/BJ20061750

Yang, E., Singh, B. K., Paustian, A. M., and Kambayashi, T. (2016a). Diacylglycerol Kinase $\zeta$ Is a Target To Enhance NK Cell Function. J. Immunol. 197, 934-941. doi: 10.4049/jimmunol.1600581

Yang, J., Zhang, P., Krishna, S., Wang, J., Lin, X., Huang, H., et al. (2016b). Unexpected positive control of NFKB and miR-155 by DGK $\alpha$ and $\zeta$ ensures effector and memory CD8 ${ }^{+}$T Cell differentiation. Oncotarget 23, 33744-33764. doi: 10.18632/oncotarget.8164

Yang, W., Gorentla, B., Zhong, X. P., and Shin, J. (2015). mTOR and its tight regulation for iNKT cell development and effector function. Mol. Immunol. 68, 536-545. doi: 10.1016/j.molimm.2015.07.022

Yoon, M. S., Sun, Y., Arauz, E., Jiang, Y., and Chen, J. (2011). Phosphatidic acid activates mammalian target of rapamycin complex 1 (mTORC1) kinase by displacing FK506 binding protein 38 (FKBP38) and exerting an allosteric effect. J. Biol. Chem. 286, 29568-29574. doi: 10.1074/jbc.M111.262816
Zamani, A., Decker, C., Cremasco, V., Hughes, L., Novack, D. V., and Faccio,

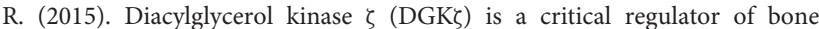
homeostasis via modulation of c-fos levels in osteoclasts. J. Bone Miner. Res. 30, 1852-1863. doi: 10.1002/jbmr.2533

Zehn, D., Lee, S. Y., and Bevan, M. J. (2009). Complete but curtailed T-cell response to very low-affinity antigen. Nature 458, 211-214. doi: 10.1038/nature07657

Zha, Y., Marks, R., Ho, A. W., Peterson, A. C., Janardhan, S., Brown, I., et al. (2006). T cell anergy is reversed by active Ras and is regulated by diacylglycerol kinase- $\alpha$. Nat. Immunol. 7, 1166-1173. doi: 10.1038/ni1394

Zhang, L., Tschumi, B. O., Corgnac, S., Ruegg, M. A., Hall, M. N., Mach, J. P., et al. (2014). Mammalian target of rapamycin complex 1 orchestrates invariant NKT cell differentiation and effector function. J. Immunol. 193, 1759-1765. doi: 10.4049/jimmunol.1400769

Zhang, N., and Bevan, M. J. (2011). CD8 ${ }^{+}$T cells: foot soldiers of the immune system. Immunity 35, 161-168. doi: 10.1016/j.immuni.2011.07.010

Zhao, C., Du, G., Skowronek, K., Frohman, M. A., and Bar-Sagi, D. (2007). Phospholipase D2-generated phosphatidic acid couples EGFR stimulation to Ras activation by Sos. Nat. Cell Biol. 9, 706-712. doi: 10.1038/ncb1594

Zheng, Y., Zha, Y., Driessens, G., Locke, F., and Gajewski, T. F. (2012). Transcriptional regulator early growth response gene 2 (Egr2) is required for $\mathrm{T}$ cell anergy in vitro and in vivo. J. Exp. Med. 209, 2157-2163. doi: 10.1084/jem.20120342

Zheng, Y., Zha, Y., Spaapen, R. M., Mathew, R., Barr, K., Bendelac, A., et al. (2013). Egr2-dependent gene expression profiling and ChIP-Seq reveal novel biologic targets in T cell anergy. Mol. Immunol. 55, 283-291. doi: 10.1016/j.molimm.2013.03.006

Zhong, X. P., Guo, R., Zhou, H., Liu, C., and Wan, C. K. (2008). Diacylglycerol kinases in immune cell function and self-tolerance. Immunol. Rev. 224, 249-264. doi: 10.1111/j.1600-065X.2008.00647.x

Zhong, X. P., Hainey, E. A., Olenchock, B. A., Jordan, M. S., Maltzman, J. S., Nichols, K. E., et al. (2003). Enhanced T cell responses due to diacylglycerol kinase $\zeta$ deficiency. Nat. Immunol. 4, 882-890. doi: 10.1038/ni958

Zhong, X. P., Hainey, E. A., Olenchock, B. A., Zhao, H., Topham, M. K., and Koretzky, G. A. (2002). Regulation of T cell receptor-induced activation of the Ras-ERK pathway by diacylglycerol kinase $\zeta$. J. Biol. Chem. 277, 31089-31098. doi: 10.1074/jbc.M203818200

Zhong, X. P., Shin, J., Gorentla, B. K., O’brien, T., Srivatsan, S., Xu, L., et al. (2011). Receptor signaling in immune cell development and function. Immunol. Res. 49, 109-123. doi: 10.1007/s12026-010-8175-9

Conflict of Interest Statement: The authors declare that the research was conducted in the absence of any commercial or financial relationships that could be construed as a potential conflict of interest.

Copyright (c) 2016 Chen, Hu and Zhong. This is an open-access article distributed under the terms of the Creative Commons Attribution License (CC BY). The use, distribution or reproduction in other forums is permitted, provided the original author(s) or licensor are credited and that the original publication in this journal is cited, in accordance with accepted academic practice. No use, distribution or reproduction is permitted which does not comply with these terms. 